\title{
Endemism in the Cladocera (Crustacea: Branchiopoda) of Southern Africa
}

\author{
Kay VAN DAMME,${ }^{*}$ Eugeniya I. BEKKER,${ }^{2}$ Alexey A. KOTOV ${ }^{2}$ \\ ${ }^{1}$ School of Biosciences, University of Birmingham, B15 2TT Birmingham, UK; ${ }^{2}$ A.N. Severtsov Institute of Ecology and Evolution, \\ Leninsky prospect 33, Moscow 119071, Russian Federation \\ *Corresponding author: kay.vandamme@gmail.com; k.p.vandamme@bham.ac.uk
}

\begin{abstract}
We review the current state of knowledge and patterns of distribution in the endemic Cladocera (Crustacea: Branchiopoda) of Southern Africa and describe two species of the Western Cape, of which one is new to science. Frey (1993), Korovchinsky (2006) and Smirnov (2008) previously suggested that South Africa harbours few endemics in the Cladocera. In the current study, we show that socalled low endemism in this region is mainly attributed to our limited state of knowledge of the local cladoceran fauna. Many of the South African taxa are ignored and revisions are lacking, as we briefly discuss for the genus Daphnia. We list known Southern African endemic Cladocera with notes on their status, map the distributions of well-studied taxa, and discuss the importance of temporary freshwater rockpools. We confirm that Southern Africa is a region of endemism for the group. We recognise three categories of endemics: i) montane endemics in the East (e.g., Drakensberg mountains); ii) endemics of the Western Cape (lowlands); iii) South African endemics, widely distributed in the region, both in the mountains and the lowlands. South African endemics have previously been regarded as relicts (Korovchinsky 2006), yet for the two taxa explored in detail in this study, there are no specific primitive morphological characters in comparison to congeners (within their respective genus/species group) and the morphology mainly suggests strong isolation. The two species belong to the Chydoridae and the Eurycercidae, respectively, and are used here as case studies for the investigation of Western Cape endemics. The first, Alona capensis Rühe, 1914 (Anomopoda: Chydoridae: Aloninae), is redescribed based on the type material. We discuss the affinities of this enigmatic species for the first time. Morphology of the habitus and the postabdomen parallel that of members of the Alona affinis-complex. The disconnected head pores and limb characters, on the other hand, place A. capensis in the Alona pulchella-group, a different lineage in the Aloninae subfamily. The specific postabdomen shape of A. capensis and a unique, inflated rostrum, diverge from the main A. pulchella-morphotype and illustrate the significant morphological isolation of A. capensis within its group. The second species, Eurycercus (Eurycercus) freyi sp.nov. (Eurycercidae), is described based on material from the collection of the late Prof. Dr. David G. Frey. It is an E. lamellatus-like taxon that is easily differentiated from the two related species (E. lamellatus and E. microdontus) by a strong indentation (with depth larger than head pore diameter) behind the head pores. E. freyi sp.nov. seems to be the closest relative of E. lamellatus. The small clade of just two species is supported by two synapomorphies: i) the rostrum is long; and ii) the spine situated on the proximal segment of the exopod of antenna II is longer than the second segment, in contrast to E. microdontus.
\end{abstract}

Key words: Cladocera, Crustacea, Alona, Eurycercus, endemism, Southern Africa.

Received: December 2012. Accepted: March 2013

\section{INTRODUCTION}

Species diversity in the branchiopod crustaceans is globally underestimated (Adamowicz and Purvis, 2005). Cladocerans, an important component of the zooplankton and zoobenthos in aquatic food webs, are a clear example (Forró et al., 2008). Taxonomy, a science out of fashion, forms a necessary basis for critical studies in ecology and biogeography of these micro-crustaceans and a realistic assessment of their global diversity (Dodson and Frey, 2001). Efforts in systematics, taxonomical capacity building and the assessment of the global Cladocera richness have now strongly increased in the Neotropics, SouthEast and East Asia (Elmoor-Loureiro, 2000; Elías-Gutiérrrez et al., 2008; Maiphae et al., 2008; Van Damme and Dumont, 2010; Kotov and Sinev, 2011), yet, unfortunately, they have decreased in Europe and North America.
In comparison, the Cladocera of the African continent have always been relatively poorly studied (Forró et al., 2008; Kotov and Taylor, 2010; Van Damme and Dumont, 2009). The continent only attracted attention sporadically after a few classic publications, e.g., by E. von Daday (1910) and G.O. Sars (1916). The literature on the African Cladocera is strongly scattered. Relatively few studies exist that deal with taxonomy or that include critical comments on identifications and systematics (Chiambeng and Dumont, 2005; Dumont, 1981; Dumont et al., 1984; Kořínek, 1984; Rey and St-Jean, 1968, 1969; Jenkin, 1954). Hence, basic faunistic studies, surveys and updated keys are urgently needed, including revisions of poorly delineated species and groups.

Recent studies indicate a significant endemism in the African Cladocera, at the species- and the genus level (Kotov and Štifter, 2005; Kotov and Taylor, 2011; Sinev, 
2006, 2008; Smirnov, 2007; Van Damme and Dumont, 2009; Van Damme and Eggermont, 2011). The endemics, as far as we know, are concentrated in a few hotspots such as the Congo basin and the southern portion of the continent. However, the picture is incomplete (Van Damme and Dumont, 2009). For the southern portion of the continent, which is known as a biodiversity hotspot, very few comprehensive faunistic revisions have been carried out for the Cladocera apart from the excellent, early works by G.O. Sars $(1895,1916)$ and a recent checklist for the Republic of South Africa (112 species; Smirnov, 2008). As a result, and, in fact, simply due to the general tendency to neglect taxonomy in most ecological papers, we can observe that species names in several ecological studies on the South African Cladocera contain severe errors [e.g., Gurenella (Guernella) raphaelis, Malacrothrix (Macrothrix) capensis, Alona diaphana (Leberis diaphanus), etc. in Lindholm et al. (2009) on the Okavango]. The general trend of disregarding a critical use of cladoceran species names in aquatic ecology, illustrates the need and the importance of continued efforts in systematics, locally as well as globally. Studies on the South African cladocerans were initiated by Sars $(1895,1916)$, Gurney (1904) and Methuen $(1910,1911)$ and later continued by Johnson (1953) and Harding (1957, 1961). Since that time, systematics of the South African Cladocera were only discussed as part of larger worldwide revisions of different groups (Smirnov, 2008), not of regional studies (Frey, 1965; Smirnov, 1971; Korovchinsky, 2004). In the last decade, Prof. Dr. N.N. Smirnov (Smirnov, 2007, 2008; Smirnov et al., 2006) and his alumni (Sinev, 2006, 2008, 2009; Kotov, 2009) started a taxonomic study on the chydorids in South Africa. Most of the latter studies are single-species descriptions. However, the status of many of the South African taxa remains unclear and needs a critical evaluation, as valid names are becoming gradually forgotten through synonymisations (e.g., in Daphnia, see Discussion).

Harbouring a mixture of Afrotropical/Ethiopic, Palaearctic, circumtropical and local endemic elements in the cladoceran fauna (Smirnov, 2008) and with a complex geological history and topography (Cowling et al., 1996), Southern Africa is a region where we can expect high diversity and endemism in the Cladocera. Endemism is well known in freshwater fish and amphibians and the Cape Fold ecoregion has been designated as an important centre for aquatic diversity (Thieme et al., 2005). In contrast to former classical divisions, Southern Africa is now claimed to be a single biogeographical region, one of the seven sub-saharan African biogeographical regions based on plants and vertebrates (Linder et al., 2012). Freshwater invertebrates are equally diverse. Endemism is well studied in the epigean freshwater decapods, such as freshwater crabs (Decapoda: Brachyura: Potamonautidae), with 74\% endemism in South Africa at the species level (Cumberlidge and Daniels, 2007), or freshwater shrimps (Decapoda: Caridae: Atyidae), with endemics that have highly restricted ranges (e.g., Caridina africana Kingsley 1882; Richard and Clark, 2009). Much of the speciation in the South African Malacostraca is linked to riverine habitats at higher altitudes (Cumberlidge and Daniels, 2007). Stagnant habitats, such as temporary rockpools, play an important role in the South African crustacean endemism as well. In the freshwater microcrustaceans, the calanoid copepods of the Western Cape show significant endemism [e.g., Lovenula simplex (Kiefer, 1929), Paradiaptomus lamellatus Sars, 1895, Metadiaptomus capensis (Sars, 1907)], all obligate temporary pool dwellers. Information on the cyclopoids and harpacticoids, though, remains scarce (Reid et al., 2000). Endemics are wellknown in the recent non-marine ostracods of South Africa (e.g., Megalocypris princeps Sars, 1898 and Leucocythere helenae Martens, 1991), many of which live in temporary freshwater systems (Sars, 1898; Martens, 1998; Karanovic, 2012). For larger branchiopods (e.g., Branchipodopsis), Southern Africa is considered a centre of speciation, with about $80 \%$ of the ca. 46 anostracan species endemic and a radiation particularly in temporary rockpools at higher altitudes (Hamer and Appleton, 1996; Hamer and Brendonck, 1997; Brendonck et al., 2000; Brendonck and Riddoch, 1997). In the Laevicaudata and Spinicaudata, several endemics have been suggested, mainly from the Eastern Cape (e.g., Eocyzicus dentatus Barnard, 1929, and Lynceus pachydactylus Barnard, 1929) (Brendonck, 1999). No effort has been made until now to comprehensively pool all data on endemism in the South African freshwater crustaceans. In particular, little attention has been paid to endemism in the South African Cladocera. Endemism is recognised here (Dumont, 1994), yet Frey (1993), Korovchinsky (2006) and Smirnov (2008) have mentioned that South Africa harbours relatively few cladoceran endemics. This is an artifact rather than a fact, resulting from our limited knowledge of the South African Cladocera.

The current manuscript is aimed to critically review our understanding of endemism in the freshwater Cladocera of Southern Africa, starting from the description of two lowland species of the Western Cape, providing comments on endemic taxa, and identifying our current gaps in knowledge. Based on available literature and samples, we discuss the main distribution patterns of the South African cladoceran endemics.

\section{METHODS}

Specimens were selected from preserved (formaline) samples under a binocular stereoscopic microscope, and studied under an optical microscope in a drop of a glycerol-formaldehyde mixture. At least two parthenogenetic 
females from each locality were dissected under a stereoscopic microscope for the study of appendages and postabdomen. Drawings were prepared using a camera lucida attached to a Leitz Orthoplan II using phase contrast and immersion oil, or an Olympus CX 41 microscope (Olympus Imaging America Inc., Center Valley, PA, USA). Stacked photographs of A. capensis were made using a mounted digital camera and compiled with HeliconFocus $^{\mathrm{TM}}$ software. For the system of seta enumeration, see previous papers (Kotov, 2007a, 2007b, 2009; Bekker et al., 2012). The homologies of different limb parts of the Anomopoda are explained in Smirnov and Kotov (2010). Drawings and photographs of A. capensis are by $\mathrm{KVD}$ and of $E$. freyi n.sp. by EIB.

For the discussion of the distribution of several endemic taxa in South Africa, we used original samples for which the geographic coordinates are known. The species in these samples were previously identified by Smirnov (2008) and were kept in his personal collection. In addition, our analysis includes older samples from other collections as well as previous literature records; in the latter cases, the approximate coordinates (degree with one decimal) were traced using the Google Earth ${ }^{\mathrm{TM}}$ portal (www.google.com/earth/index.html).

\section{RESULTS}

Alona capensis Rühe, 1914 (Figs. 1-3)

Alona capensis Rühe, 1914; Smirnov, 1971

\section{Taxonomical account}

Type locality: Simonstown, Western Cape, South Africa (for the lectotype). Approximate coordinates: $34.17^{\circ} \mathrm{S}, 18.42^{\circ} \mathrm{E}$. Rühe (1914) did not list this locality (Rifle Range bei Simonstown) among his samples including A. capensis, yet the specimens from Simonstown are the only ones present at the Zoologisches Museum für Naturkunde der Humboldt-Universität (ZMHU) (Berlin, Germany), and were therefore deposited as type material.

Type material: three adult parthenogenetic females, the largest is designated here as the lectotype, others are paralectotypes. This material comes from the collection of the Museum für Naturkunde Berlin (Accession number 17469 ), and from the Lakeside bei Simonstown, Western Cape, Leg. Deutsche Südpolar Expedition 1901-1903 (Rühe, 1914).

Short diagnosis: parthenogenetic female. Body elongated, postero-ventral angle widely rounded, without any

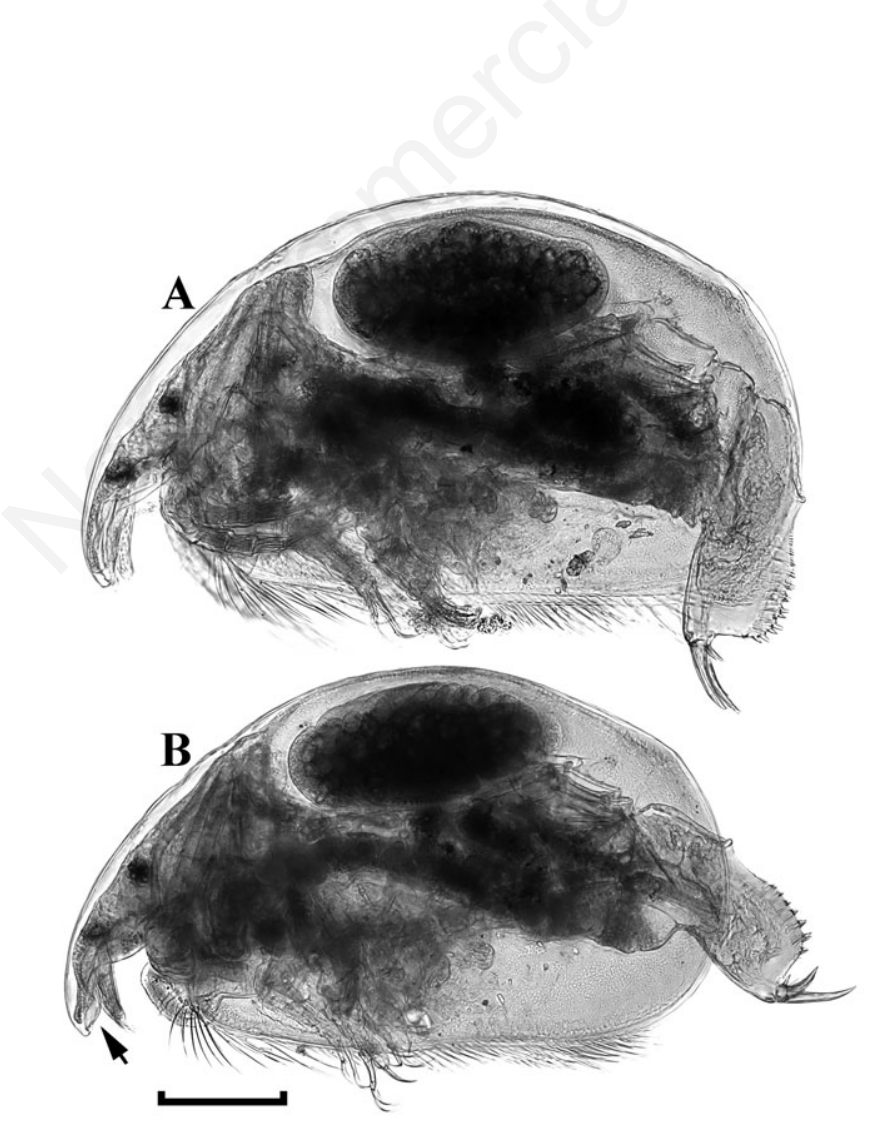

Fig. 1. Alona capensis Rühe, 1914, adult parthenogenetic females from type series, from Lakeside bei Simonstown, Western Cape, Republic of South Africa. A. Lateral view. B. Idem, smaller specimen, arrow indicating the peculiar, inflated rostrum of this species. Scale bar $=0.2 \mathrm{~mm}$. 
notches or denticles. Body moderately lacking a median keel. Rostrum relatively long, with a relatively thin tip and a posterior bulge. Posterior portion of head shield undulated; three main head pores disconnected, the postpore distance $=1 / 2$ interpore distance; lateral pore $1 / 2$ interpore distance from midline. Labrum with a large median keel having two series of minute setules on posterior margin. Valve with an anterior group of long, spread marginal setae at antero-ventral angle. Postabdomen short, with sub-parallel ventral and dorsal margins; anal margin as long as postanal margin and shorter than preanal margin. Dorso-distal angle widely rounded. Marginal teeth short, each accompanied with a very minute denticle; lateral fascicles do not extend beyond the dorsal margin, first setule in each fascicle stronger than others. Postabdominal claw with basal spine strong, with length more than claw diameter at base. Antenna I with sensory seta implanted approximately in middle and four groups of setules. Antenna II, setae: 0-0-3/1-1-3; spines: 1-0-1/0-0-1. Limb I with accessory seta; outer distal lobe (ODL) with a single large seta; inner distal lobe (IDL) with three setae; endite 3 with large anterior seta; endite 2 and 1 each with a rudimentary anterior seta; gnathobase I absent. Filter plate II of seven setae. Exopodite III with seven setae, setae 1 and 2 specific, filter plate III of seven setae. Exopodite IV with six setae, setae 1-3 short, seta 4 longest, filter plate IV of five setae. Limb V without a filter plate. Limb VI absent. Ephippial female, male unknown. Size up to $0.62 \mathrm{~mm}$.

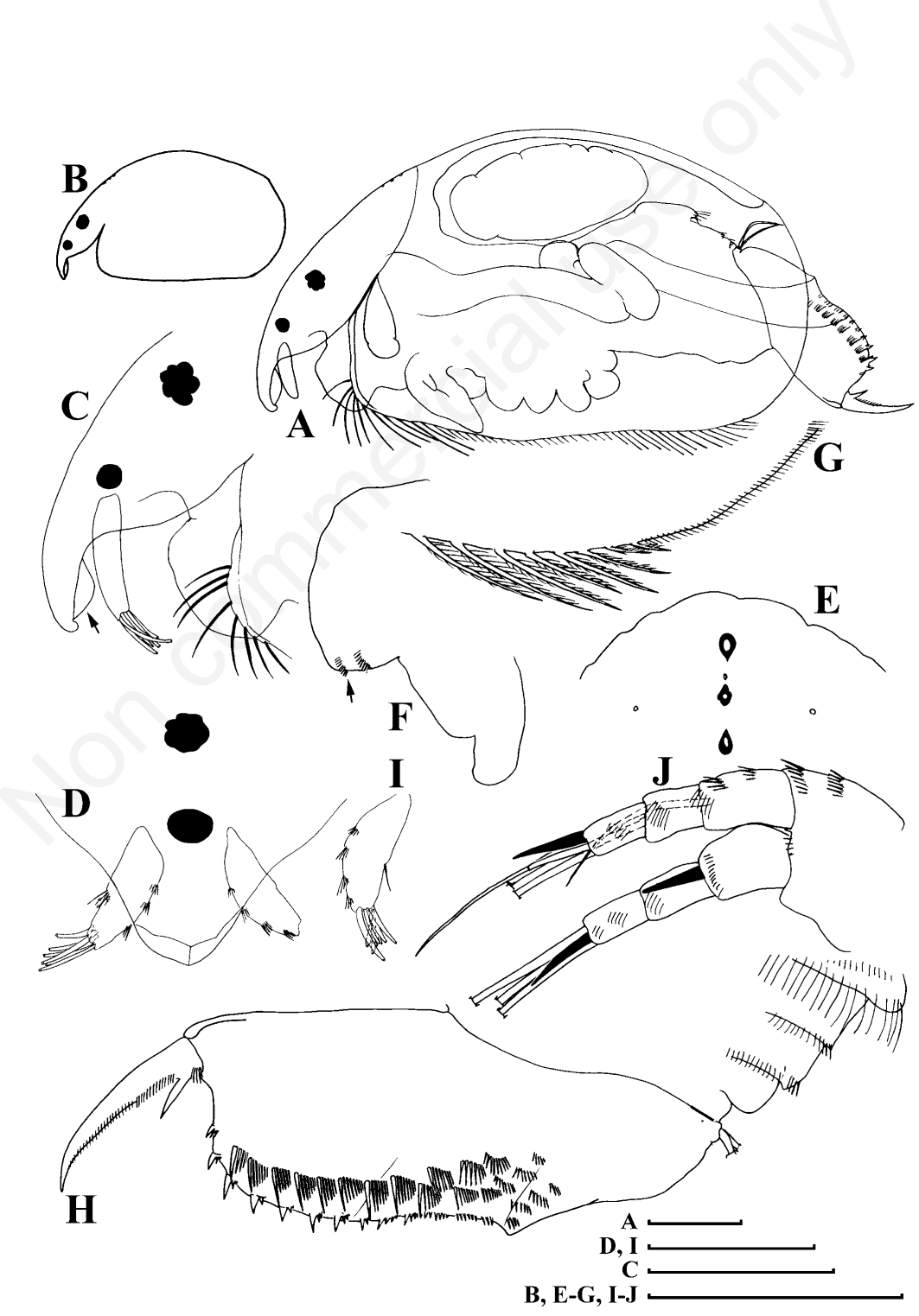

Fig. 2. Alona capensis Rühe, 1914, adult parthenogenetic females Lakeside bei Simonstown, Western Cape, Republic of South Africa. A-B, lateral view of adults; C-D, head, lateral and ventral view; E, posterior portion of headshield; F, labrum; G, valve postero-ventral portion; H, postabdomen; I, antenna I; J, antenna II. Scale bar=0.2 mm (A), $1 \mathrm{~mm}(\mathrm{~B}), 0.05 \mathrm{~mm}(\mathrm{C}-\mathrm{H})$. 


\section{Redescription}

Parthenogenetic female: body subovoid, elongated, relatively transparent. Dorsal margin regularly arched from tip of rostrum to postero-dorsal angle; posterior margin regularly convex; postero-ventral angle widely rounded, without any notches or denticles; ventral margin almost straight (Figs. 1, 2A, and 2B). Body moderately compressed laterally, lacking a keel. Head small, rostrum relatively long, with a relatively thin tip and a posterior bulge (Fig. 2C, arrow), aesthetascs projecting beyond the tip of rostrum. Eye larger than ocellus in lateral view, but in dorsal view they are of subequal size (Fig. 2C and 2D). Posterior portion of head shield undulated; three main head pores of the same size, disconnected, the postpore distance (between posterior main pore and posteriormost point of headshield $)=1 / 2$ interpore distance (=distance between anteriormost and posteriormost main pore); a small lateral pore on each side at $1 / 2$ interpore distance from midline (Fig. 2E). Labrum with a fleshy body, a boot-like distal labral plate and a large median keel having slightly undulated anterior margin, rounded apex and convex posterior margin supplied with two series of minute setules (Fig. 2F). Valve without reticulation, with a group of long, spread setae at antero-ventral angle, then short setae, then longer setae at posterior portion of ventral margin; a submarginal row of setules at posterior margin, on inner face of the valve (Fig. 2G).

Postabdomen short, with sub-parallel ventral and dorsal margins (Fig. 2H). Ventral margin straight; preanal margin S-shaped, anal margin as long as postanal margin and shorter than preanal margin. Preanal margin distinct, while postanal margin absent, dorso-distal angle widely rounded, distal margin straight. Marginal teeth about 10-13, short, each accompanied with a very minute denticle. Lateral fascicles of long setules do not extend beyond the dorsal margin, decreasing in size anteriorly; first setule in each fascicle stronger than others. Postabdominal claw strong, as long as preanal margin, curved distally. Basal spine strong, with length more than claw diameter at base. Two pectens of setules along dorsal margin of claw.

Antenna I about three-four times as long as wide, sensory seta short, implanted approximately in middle, four groups of setules on dorsal margin; aesthetascs of unequal size distally (Fig. 2D and 2I). Antenna II (Fig. 2J) with basal segment supplied by series of setules. Setae: Setae $0-0-3 / 1-1-3$; spines: 1-0-1/0-0-1. Seta on proximal exopod segment reaches distal end of next segment, apical spines as long as apical segments, or longer.

First maxilla with two setulated setae (Fig. 3A).

Limb I large (Fig. 3B), accessory seta short (Fig. 3C acs), ODL (Fig. 3C) with a single large seta; IDL with three setae, one small and naked, two larger, subequal, unilater- ally armed with fine setules in distal half. Endite 3 (Fig. 3D en1) with three posterior (soft) setae (Fig. 3B, and 3D a-c), anterior seta relatively large (Fig. 3B, and 3D 1). Endite 2 with three posterior setae (Fig. 3D d-f) and a rudimentary anterior seta (Fig. 3D 2). Endite 1 with two posterior setae (Fig. 3D g-h) and a rudimentary anterior seta (Fig. 3D 3). Rows of setules on ventral part of limb corm descreasing in size distally. Ejector hooks well-developed, subequal in size (Fig. 3B ejh). Gnathobase I not found.

Limb II triangular, exopodite large, lacking any setae with groups of setules (Fig. 3E ext). Inner limb portion with eight scrapers of size gradually decreasing toward gnathobase. No soft seta near scrapers. Distal armature of gnathobase with three setae. Filter plate with seven setae, of which the first one shorter than others and with inflated base.

Limb III with exopodite bearing seven setae, among five distal setae (Fig. 3E 1-5), setae 1 and 2 specific: seta 1 short and armed distally by short spinules; seta 2 armed distally by both spinules and long setules; two lateral setae (Fig. 3E 6-7) of similar size, plumose. Inner limb portion with distal endite bearing three anterior setae (Fig. 3H 13 ), two distal setae with short spinules; basal endite with four anterior setae (Fig. 3I 4-7), a large sensillum near seta 4 base; four posterior setae plumose (Fig. 3H a-d). Distal armature of gnathobase with four setae, among which a strong sensillum (Fig. 3J 1); filter plate of seven setae.

Limb IV with pre-epipodite (Fig. 3K pep) round, implanted with long marginal setules and epipodite of same size. Exopodite square and large, bearing six setae (Fig. 3K 1-6), setae 1-3 short, seta 4 longest. Proximal margin of the exopodite undulated and implanted with a row of small setules. Inner limb portion with four marginal setae, of which the first with short denticles (Fig. 3L 1) in its distal half, the following three are long flaming torch setae (Fig. 3L 2-4), three soft setae on posterior limb face (Fig. $3 \mathrm{~L} \mathrm{a-c)}$. Distal armature of gnathobase with four s etae, among which a large sensillum. Filter plate of five setae.

Limb V with large pre-epipodite and epipodite (Fig. 3M pep, epp). Exopodite a large flap (Fig. 3M), with fourth a short distal seta (Fig. 3M 1) and three lateral setae (Fig. 3M 2-4), setules between the former and the latter. Inner limb portion (Fig. 3M ilp) as a large flap bearing thick long setules on its ventral margin; two marginal setae, first one bent over the inner lobe, second exceeding half the proceeding seta, both with long setules. Gnathobase reduced, as a setulated process with a minute projection.

Limb VI absent.

Ephippial female, male: unknown.

Size: $0.58-0.63 \mathrm{~mm}$.

Differential diagnosis: A. capensis Rühe, 1914 is easy to recognise without a dissection and is easily discriminated from A. cambouei Guerne and Richard, 1893 - an- 
other species of the A. pulchella-group that is present in the region and common in Africa (Fig. 4). The body of $A$. capensis is elongate, while the postabdomen is short. The rostrum has a posterior bulge in lateral view and the valve has a conspicuously long frontal group of setae. The postabdomen lacks a sharp, protruding dorso-distal angle, has short marginal denticles and lateral fascicles that do not extend beyond the dorsal margin. The postabdominal claw bears a thick basal spine. After dissection, the three disconnected head pores (as in A. cambouei and in con-

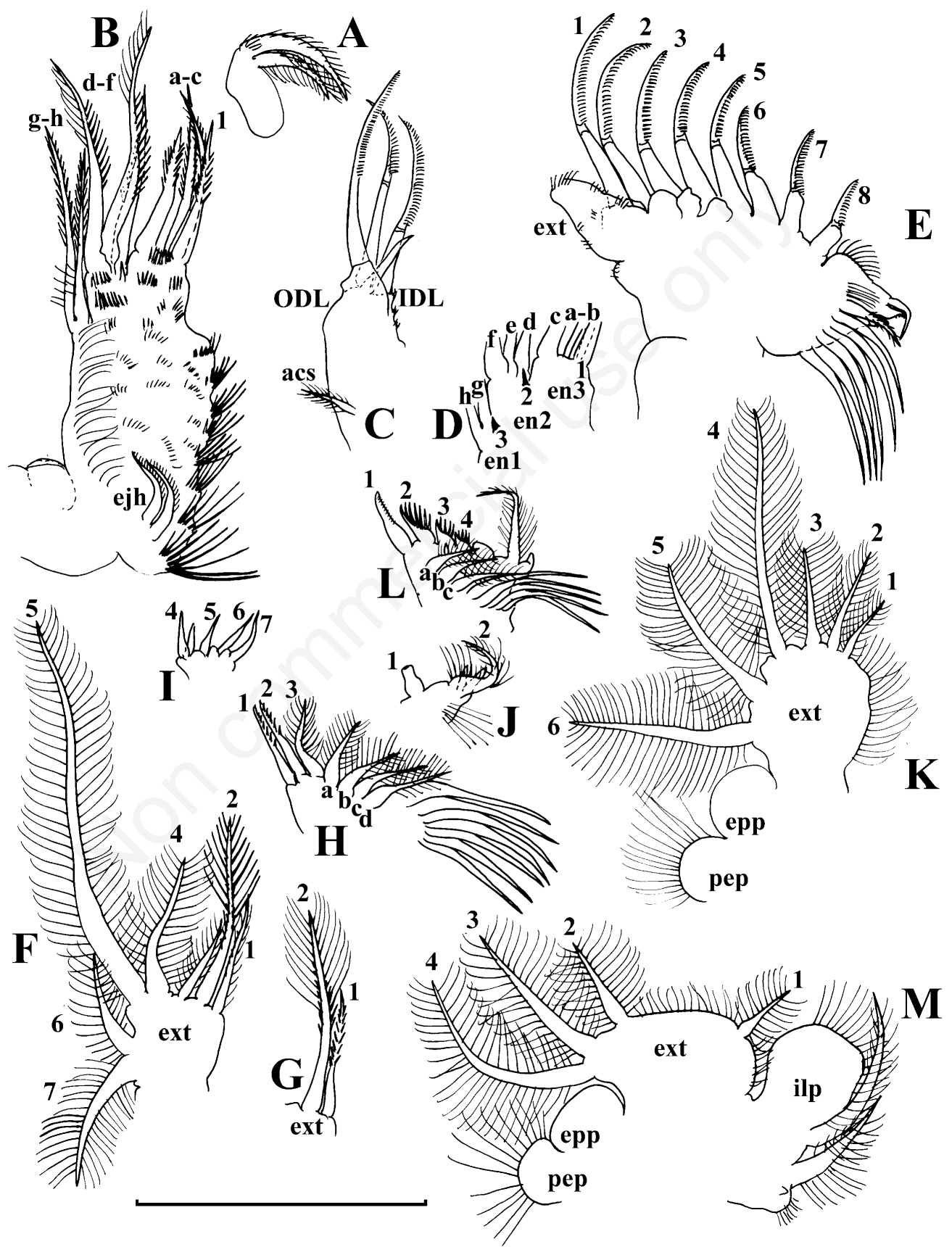

Fig. 3. Alona capensis Rühe, 1914, maxilla I and limbs of adult parthenogenetic females Lakeside bei Simonstown, Western Cape, Republic of South Africa. A, maxilla I; B, limb I; C, its distal portion; D, its endites; E, limb II; F, exopodite III; G, its two setae; H, inner portion of limb III; I, basal endite of limb III; J, distal armature of gnathobase I; K, exopodite IV; L, inner portion of limb IV; M, Limb V. Scale bar $=0.05 \mathrm{~mm}$. 
trast to taxa such as $A$. affinis and A. quadrangularis) and the ventral setules on the labral keel (which are absent in A. cambouei but present in A. affinis and A. quadrangularis) are useful to recognise $A$. capensis.

Comments: Rühe (1914) included no drawings when describing the species. Later, Smirnov (1971) listed $A$. capensis in his monograph as a valid species, depicting the habitus and postabdomen for the first time. Limb morphology of the species and therefore phylogenetic affinities remained unknown and the animal was never recognised again in nature since Rühe (1914). Smirnov (2008) did not include the taxon in his checklist of South Africa.

The limb morphology and the three disconnected head pores place $A$. capensis in the $A$. pulchella-group. Characters of the $A$. pulchella-group were discussed and listed in Van Damme and Dumont (2008b); still, the position of this species complex relative to the central Alona is still unclear. The $A$. pulchella-complex is a large group within Alona sensu lato, with conserved limb morphology and a number of reductions, making their relation with the sixlimbed Alona's (the Hexalonas, like $A$. affinis-, A. intermedia-, A. guttata, A. costata-groups etc.) difficult (Van Damme and Dumont, 2008b). Most of the currently remaining Alona species group are actually lineages with a separate evolution, ecology and radiation within, waiting for revision to determine its final delineation to the core (e.g., Anthalona; Van Damme and Dumont, 2008b; Van Damme et al., 2011).

The shape of the postabdomen, an otherwise useful character for deriving first-hand affinities in the chydorids, is misleading here. A. capensis has a postab- domen that is atypical for adults of the A. pulchellagroup. The only other known representative of the $A$. pulchella-complex in Africa is Alona cambouei, which, however, is very different in morphology. In habitus and postabdomen, $A$. capensis differs from the latter (more elongate body and less elongate postabdomen), though it shares the three disconnected main head pores and the limb characters. A few characters are unusual for $A$. capensis within the A. pulchella-complex: i) rows of ventral setules on the labral keel; ii) peculiar bulge on the inner side of the rostrum, even unique within the Chydoridae; iii) long, spread, frontal setae on the valve margin; and iv) shape of the postabdomen, lacking a protruding dorso-distal corner that is typical for most species in this group. These characters suggest a significant divergence from the general pulchella-morphotype and leave $A$. capensis as a singleton within the group. There is no divergence in limb morphology from the basic $A$. pulchella-complex, a group in which limbs are fairly conserved, so $A$. capensis is definitely not a genus in its own right. Nevertheless, the divergence in external features is significant.

There are two striking features in the morphology of A. capensis. The first is the character state of ventral setules on the labral keel. The state is typical for six-limbed Aloninae or directly derived groups (A. affinis, A. guttata, A. quadrangularis, etc.), but not for the A. pulchella-complex. A. pulchella and related species lack this group of setules. The second is the postabdomen shape. It is not typical for adult species of the $A$. pulchella-group to have such a postabdomen and the $A$. capensis-state seems to be more similar to $A$. affinis or to the peculiar Baikal endemic

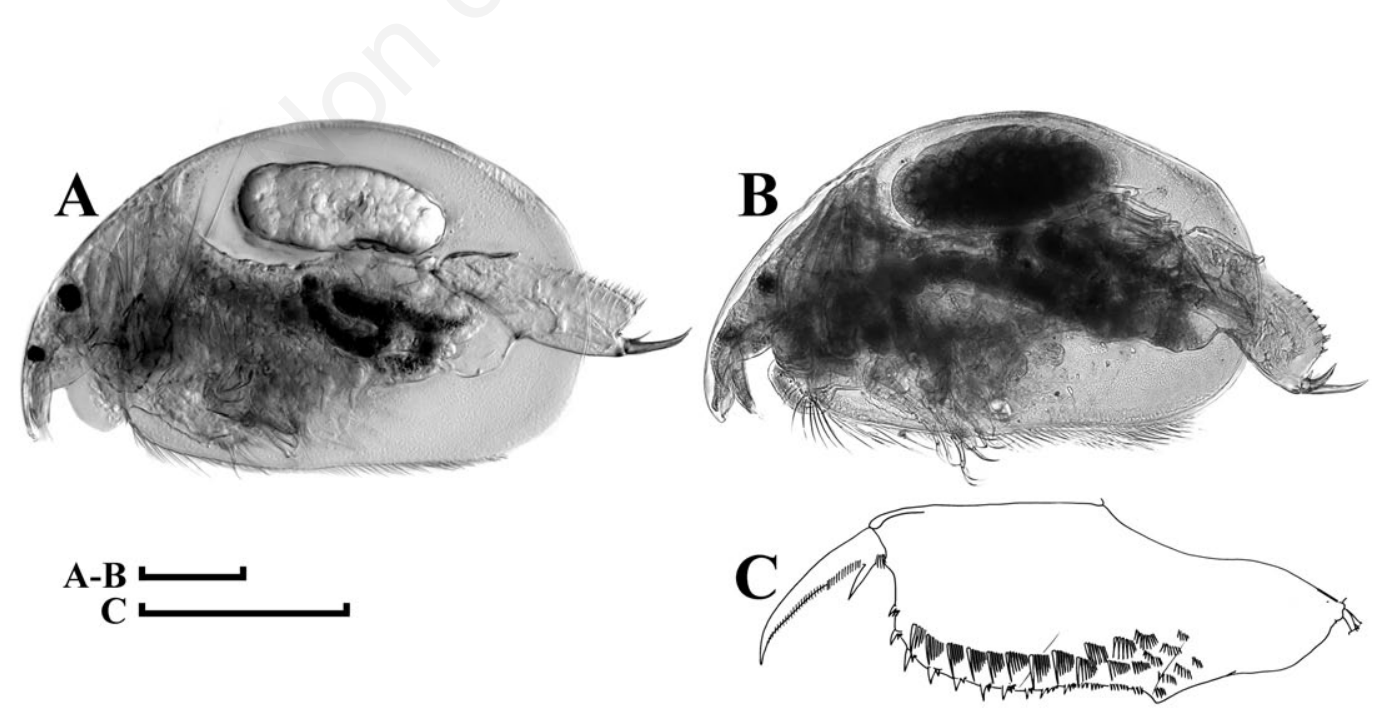

Fig. 4. Comparison of Alona cambouei (A) and A. capensis (B and C), the two African species of the A. pulchella-complex. A) Habitus adult parthenogenetic female of $A$. cambouei from Okavango (Leg. R. Hart and H.J. Dumont); B) habitus adult parthenogenetic female of $A$. capensis from type series; C) idem, drawing postabdomen (compare with straight postabdomen in A). Scale bar of A-B) $=0.2 \mathrm{~mm}$, and of $\mathrm{C})=0.05 \mathrm{~mm}$. 
A. setosocaudata Vasiljeva and Smirnov, 1969. These two states in A. capensis (shape of the postabdomen and labral keel setules) could mean that i) the $A$. pulchella-complex derived from a Hexalona ancestor, expressing in A. capensis through reversal or, possibly, a true ancestral condition (labral setules); ii) either or both of these characters derive from convergence and do not indicate a link. For example, the postabdomen shape might result from evolutionary constraints in the morphology and homoplasy. Both hypotheses are possible. For the first, it is not unlikely that the A. pulchella-group derived from six-limbed animals and that a connection still exists, perhaps also in other taxa of this species complex. For the second, convergence in postabdomen shape also occurs in the $A$. pulchella-group with $A$. azorica, yet in a different direction, resulting in a postabdomen that is almost identical to that of Coronatella rectangula (former Alona rectangula). Furthermore, the postabdomen of the young $A$. pulchella and $A$. cambouei lacks a protruding sharp dorso-distal angle and is similar to that in adult $A$. capensis.

A. capensis is a peculiar member of its group (the $A$. pulchella-complex). Such a divergence within the species complex is striking, and was found in the Mediterranean endemics A. azorica and A. nuragica (Crosetti and Margaritora, 1985; Frenzel and Alonso, 1988; Alonso, 1996; Sinev et al., 2012), and in A. nigra as well (Kotov et al., 2010), which deviate in postabdomen from the general $A$. pulchella-morphotype. As species of the A. pulchellagroup are well adapted to temporary pools, isolation in larger regions of strong aridity such as the Mediterreanean or Southern Africa, might have increased chances of local speciation over time. A divergent speciation in postabdomen shape is a process that apparently occurred more than once independently in this small chydorid lineage, at least twice in the Mediterranean and once in the Western Cape.

Distribution: A. capensis is only found in its type locality and two closest localities in the Western Cape, and has not been recorded since Rühe (1914) (Tab. 1). The $A$. pulchella-group is cosmopolitan, including the widespread A. glabra, A. cambouei and A. pulchella, with most of its species being confined to warm regions, with few exceptions (e.g., A. karelica; Van Damme et al., 2010). From the Mediterranean, over lowland Africa, reaching the South (e.g., Okavango), one species of this group dominates: the common A. cambouei. A. capensis is the second species of the A. pulchella-group on the African continent.

Eurycercus (Eurycercus) freyi sp.nov. (Figs. 5-7) Eurycercus lamellatus (Müller) in Harding, 1961; Eurycercus gr. lamellatus in Seaman et al., 1999; Eurycercus (Eurycercus) sp. in Frey 1993; Eurycercus sp. in Smirnov, 2008.

\section{Taxonomical account}

Etymology: the taxon is named in honour of Prof. Dr. David G. Frey (10.10.1915 - 01.04.1992), one of the best appreciated researchers of the Cladocera of the $20^{\text {th }}$ century, who determined the populations from the Cape as Eurycercus (Eurycercus) sp. (Frey, 1993). More precisely, these samples were used here for description of $E$. (E.) freyi sp.nov.

Type locality: Bookekraal \#3, long channel away from road, across river from Worcester, Western Cape province, Republic of South Africa. Approximate geographic coordinates: $33.6^{\circ} \mathrm{S} ; 19.5^{\circ} \mathrm{E}$. The type series was collected in 22.10 .1990 by D.G. Frey.

Holotype: a parthenogenetic female $2.03 \mathrm{~mm}$ in $90 \%$ ethanol from type locality, deposited in the National Museum of Natural History [former United States National Museum (USNM)], Smithsonian Institution, Washington, DC, USA [accession (catalogue) number USNM 1202979 for the holotype].

Paratypes: two tubes with selected females from type locality, collected by D.G. Frey, (accession number USNM 1202980). Other material examined here is presented in Tab. 2.

Short diagnosis: adult parthenogenetic female. Dorsal head pores on a transverse fold in posterior portion of head shield, with a strong indentation (with depth larger than head pore diameter) behind it. In anterior view, body moderately compressed laterally, median keel passes through whole carapace dorsum and begins on the head shield behind head pores. Rostrum comparatively long. Ocellus minute. Lateral head pore elongated along longitudinal body axis. Labrum with a narrow median keel, terminating in an angled apex protruding beyond distal end of antenna I. Postabdomen with sub-parallel dorsal and ventral margins, preanal teeth pointed. Spines at postanal border large, grouped. Spines at base of pre-claw portion (anal-postanal border and distal part anal border) short, predominantly double. Antenna I with antennular sensory seta arising slightly distally to its middle. Denticles in rows encircling antennular surface small. On antenna II, spine situated on proximal segment of exopod longer than second segment. Limb I IDL with a hook-like seta equal in thickness or only somewhat thicker than longest seta, smallest seta of IDL very short. Inner distal lobe with 8-9 distal, 9-11 proximal and 4 basal spinules, marginal group of spinules reduced. Exopodit IV with 6 setae, exopodit V with 7 setae. Eight setae in filter plate II, 9 setae in filter plate III; 9 setae in filter plate IV, 8 setae in filter plate V. Intestine has a single loop. Size up to $2.27 \mathrm{~mm}$.

\section{Description}

Parthenogenetic female: in lateral view body subovoid (Fig. 5A), maximum height of the body in its mid- 


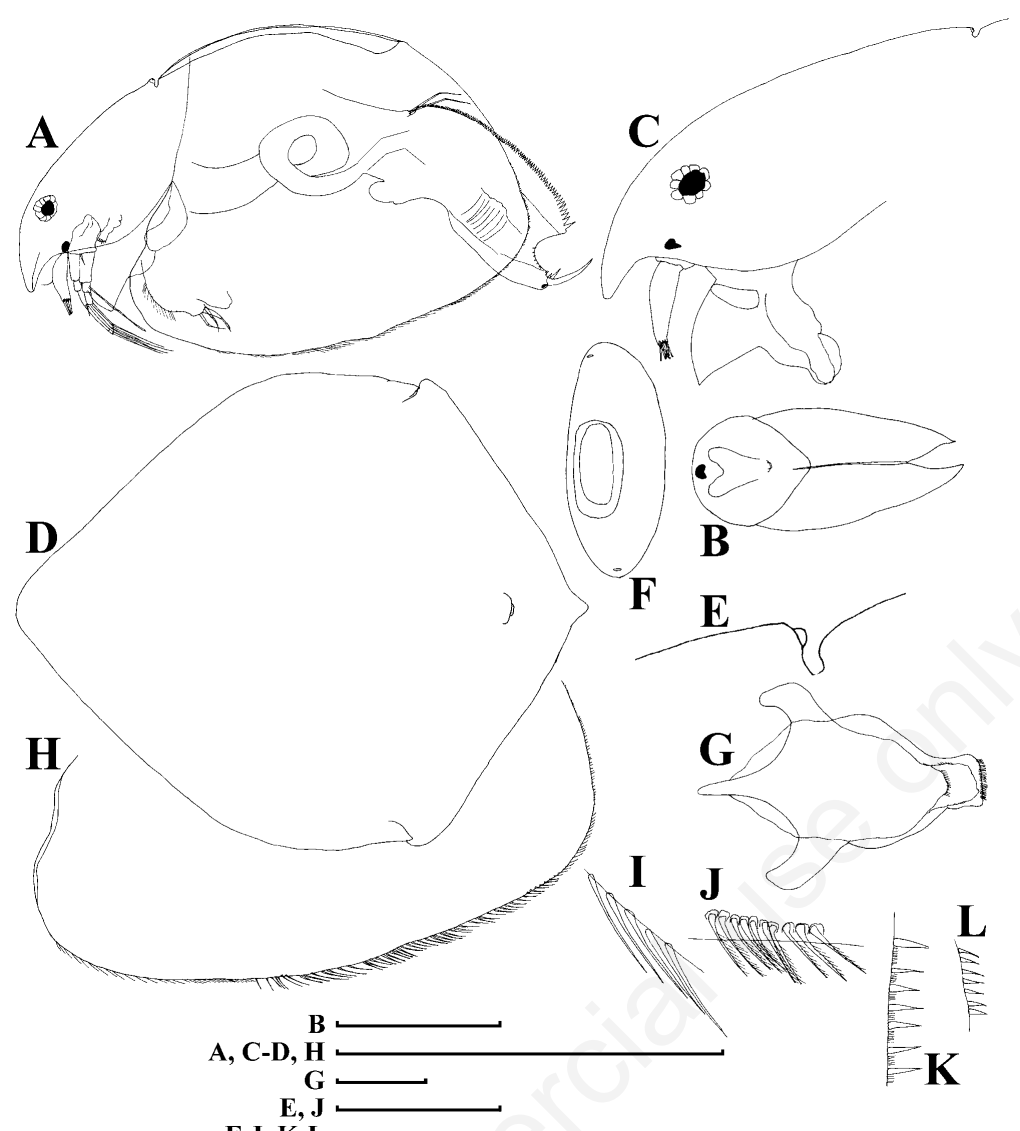

Fig. 5. Eurycercus (Eurycercus) freyi sp.nov., parthenogenetic female from Bookekraal \#3, Western Cape province, Republic of South Africa. A, lateral view; B, dorsal view; C, head in lateral view; D, head shield; E-F, head pore in lateral and dorsal view; G, labrum, ventral view; H, valve; I, setae at antero-ventral portion of valve; J, setae at posterior half of ventral portion of valve; K, armature of posterior valve margin; L, idem, more dorsal portion. Scale bar=1 mm (A-D, H); $0.1 \mathrm{~mm}(\mathrm{E}-\mathrm{G}, \mathrm{I}-\mathrm{L})$.

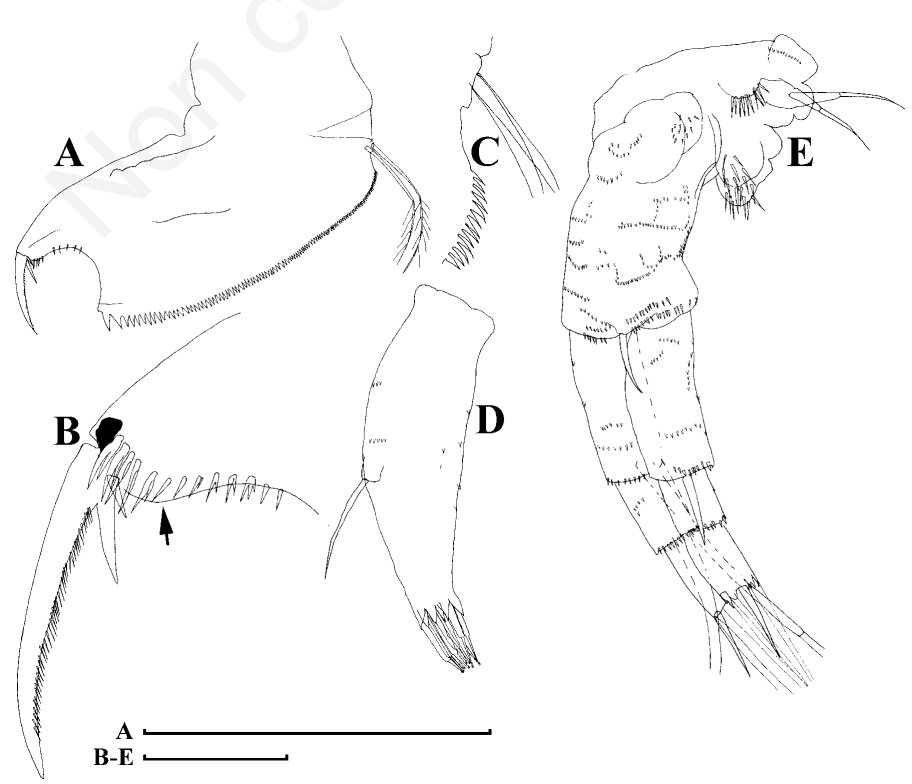

Fig. 6. Eurycercus (Eurycercus) freyi sp.nov., parthenogenetic female from Bookekraal \#3, Western Cape province, Republic of South Africa. A, postabdomen; B, its distal portion, the arrow indicating postanal angle obtuse, rounded; C, its proximal portion; D, antenna I; E, antenna II. Scale bar=1 mm (A); $0.1 \mathrm{~mm}(\mathrm{~B}-\mathrm{E})$. 
dle portion. Dorsal margin in general even, slightly convex, but interrupted by a prominent transverse fold with head pores, a strong depression (with depth larger than head pore diameter) posteriorly to it. Postero-dorsal angle rounded, posterior margin slightly convex, postero-ventral angle broadly rounded. In anterior or dorsal view, body moderately compressed laterally, maximum width of body at level of mandibular articulation. Median dorsal keel passes through whole carapace dorsum and begins on head shield behind head pores (Fig. 5B). Intestine has a single loop, posterior intestinal caecum present. Head large, with dorsal margin regularly arched from rostrum to region of dorsal head pores (Fig. 5C). Border line between head shield and valves obscure in preserved animals in lateral view, but quite distinct in dorsal view (Fig. 5B). Rostrum comparatively long. Compound eye rather large, located near dorsal margin of head markedly closer to rostral extremity than to head pores. Ocellus small, located near antenna I base, closer to eye than to tip of rostrum. A single major head pore as a ringed, suboval field of special cuticle located on a prominent transverse fold (Fig. 5D and 5E). Each lateral pore minute, elongated along longitudinal body axis and located at either side of major pore, relatively closer to it (Fig. 5F). Labrum a fleshy body, with a narrow median keel (Fig. $5 \mathrm{C}$ and $5 \mathrm{G}$ ), terminating in a well-developed angled apex, protruding beyond distal end of antenna I. Keel anterior margin convex, without setulation, posterior margin straight. Distal labral plate with rich setulation. Paired lateral projections on labrum well-developed, horn-like, with apexes directed anteriorly (Fig. 5G). Valves with very obscure reticulation; antero-ventral portion slightly prominent anteriorly as a flap (Fig. $5 \mathrm{H})$. Continuous row of setae along ventral rim of valves, in anterior portion they are long (Fig. 5I), then decreasing in size, then sharply increasing in size posterior to the prominence on ventral margin (Fig. 5J), and finally gradually decreasing in size to postero-ventral valve portion. Postero-ventral angle with a row of spinules, with minute setules between them (Fig. 5K). This row continues to ventral portion of posterior margin, but there are no setules between setae there (Fig. 5L). Abdomen thick; no abdominal projections on dorsal part of all segments. Postabdomen as a large, relatively broad, flattened plate (Fig. 6A), with subparallel dorsal and ventral margins. Dorso-distal (preanal) angle well expressed, distal anal embayment deep, dorsal portion of distal (=anal) margin slightly concave. Postanal angle obtuse, rounded (Fig. 6B, arrow). Preclaw portion of postabdomen as a conical prominence. Ventral margin of postabdomen even. Armature of the preanal margin as a series of preanal teeth, slightly and fluently increasing in size in distal direction; a gap lacking any teeth at base of postabdominal setae (Fig. 6B); 89-102 teeth in middle of preanal margin with sharp tips; distalmost tooth somewhat larger than the others, located just on dorso-distal angle of postabdomen. On pre-claw portion of postabdomen there are crescentic clusters postanal teeth, distalmost members particularly large, predominantly clustered, teeth at base of pre-claw portion short, predominantly doubled (Fig. 6B). Sub-parallel rows of minute setules on whole lateral surface of postabdomen (not represented in Fig. 6A due to their minute size). Postabdominal setae short (less than third of preanal margin length), bisegmented, distal segment slightly shorter than basal one and bilaterally setulated. Setae located on a distinct, nut-like base (Fig. 6C). Postabdominal claw robust, with massive base; weakly and evenly tapered in distal direction, and slightly curved. Two basal spines, first (distal) long, second (basal) short, located dorsally immediately at base of claw.

Antenna I elongated; its length about three times more than width. Maximal width in basal half, with its distal $2 / 3$ portion evenly tapering distally (Fig. 6D); protruding greatly beyond tip of rostrum (Fig. 5A and 5C). Slender antennular sensory seta relatively short (about third of antenna I length), arising slightly distal, than antenna I middle. Nine bisegmented esthetascs, with pointed teeth around them. Numerous short rows of minute denticles encircling antennular surface. Antenna II relatively short (Fig. 5A). In coxal region, a projection with two bisegmented setae, unequal in length, next projection with semi-circular row of setules and a distalmost projection with numerous strong spinules (Fig. 6E). Massive basal segment with a relatively long seta distally on anterior surface, and rows of short setules. Both branches with elongated segments, basal most members particularly elongated; all segments with rows of short setules. Setae $0-0-3 / 1-1-3$; both apical and lateral setae long, clearly bisegmented, with long hairs on both basal and distal segments. Spines 1-0-1/0-0-1. No additional spines on distal parts of any segments of either branch. Length of apical spines and of segments from which they arise sub-equal; spine situated on proximal segment of exopod shorter than second segment.

Limb I large. Epipodite (not represented in Fig. 7A) without a finger-like projection. Two accessory setae (Fig. 7B acs), unequal in size and setulated in distal parts, are the distalmost structures of the distal portion of limb I. Outer distal lobe distally with 2 setae of very unequal size (Fig. 7A ODL); IDL (Fig. 7A IDL) with three bisegmented setae, one of them a remarkable relatively strong hook-like seta (but less strong as E. macracanthus), the smallest IDL seta short (Fig. 7C and 7D). Inner distal lobe supplied with long distal spinules (about 8-9 in largest adults) (Fig. 7D dis), long proximal spinules (about 9-11 in largest adults) (Fig. 7D pro), and very short basal spinules (about 3-4 in largest adults) (Fig. 7D bas), marginal group of spinules reduced; a field of minute denticles on IDL basally. Endite III with 
three setulated, bisegmented posterior setae of similar size (Fig. 7A a-c), and a setulated, stiff anterior seta 1. Endite II with three posterior setae (Fig. 7A d-f) and a stiff, setulated anterior seta 2, a very small sensillum near its base. Endite I with 3 posterior setae (Fig. 7A g-i), and a stiff anterior seta 3. Two ejector hooks (Fig. 7A ejh) anteriorly on outer portion of limb corm. Well-developed maxillar process bearing three slender, fully and densely setulated setae on inner side of limb base.

Limb II with ovoid epipodite lacking a finger-like projection; exopodite as a small lobe (Fig. 7E). At inner side of limb, a row of eight stiff scrapers (Fig. 7E 1-8); setae 1-2 with more delicate feathering, setae 3-8 with relatively robust denticle. Posteriorly on limb corm 8 soft setae: dis-

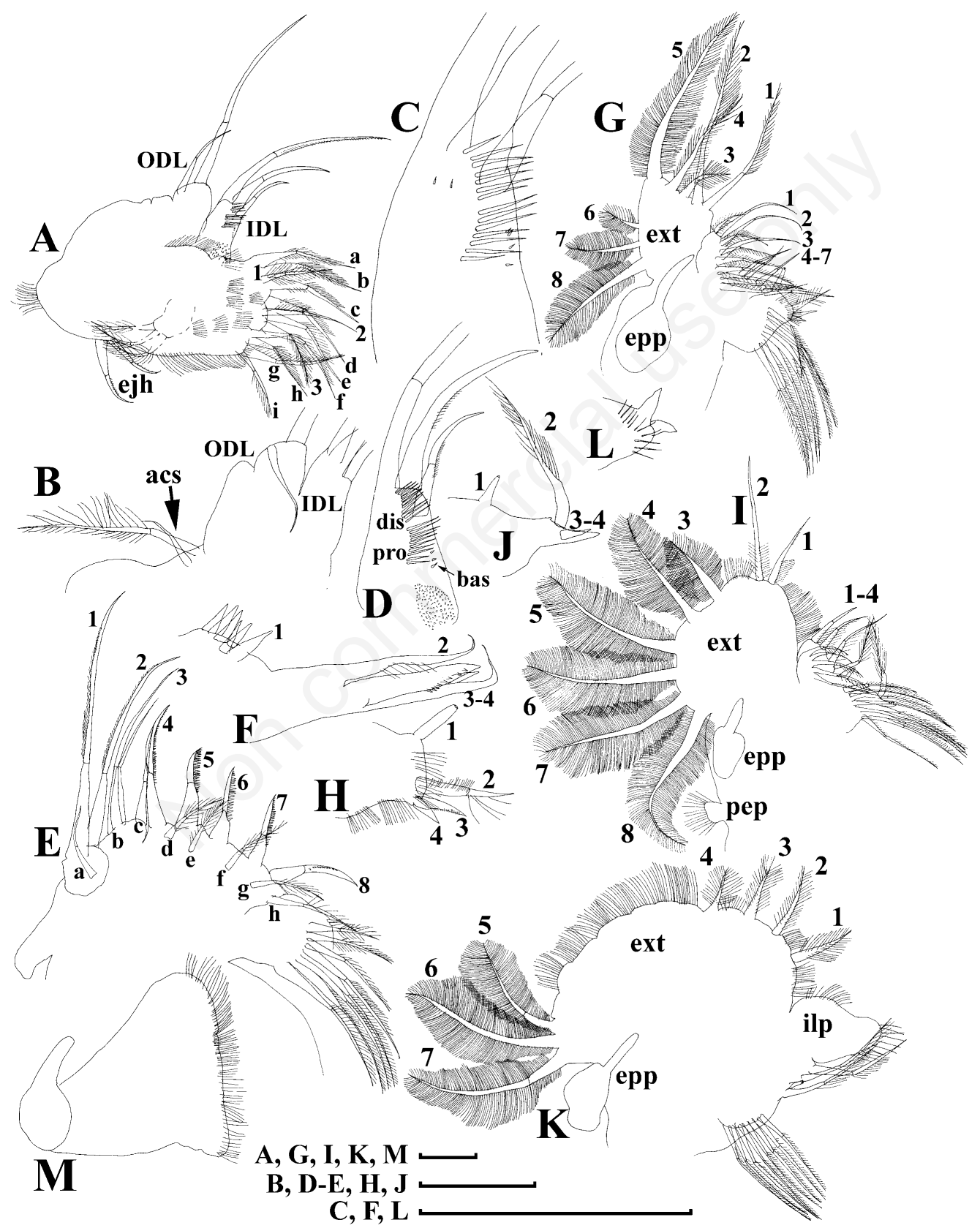

Fig. 7. Eurycercus (Eurycercus) freyi sp.nov., thoracic limbs of parthenogenetic female from Bookekraal \#3, Western Cape province, Republic of South Africa. A, limb I; B, its distal portion; C-D, armature of IDL; E, limb II; F, distal armature of its gnathobase; G, limb III (ext setae 1-8) and endite setae 1-7; H, distal armature of its gnathobase; I, limb IV (ext setae 1-8 and endite setae 1-4); J, distal armature of its gnathobase; K, limb V; L, distal armature of its gnathobase; M, limb VI. Scale bar=1 mm. 
talmost one (Fig. 7E a) short; next two ones (Fig. 7E b-c) longest, basal most ones (Fig. 7E d-h) similarly feathered by long hairs. Distal armature of gnathobase with four setae (Fig. 7F 1-4) one of them a relatively large sensillum (Fig. 7F 1), located far from the others, a row of denticles (about 5 in largest adults) crossing near it. Filter plate with 8 long, densely setulated setae; distalmost seta of filter plate clearly smaller than the others, second-third ones slightly shorter than others.

Limb III with relatively large epipodite (Fig. 7G epp) bearing a finger-like projection. Exopodite (Fig. 7G ext) flat, distally with five setae of unequal size (Fig. $7 \mathrm{G}$ ext 1-5); lateral group consists of three setae (Fig. 7G ext 68 ) increasing in size basally. Distal endite with three bisegmented anterior setae (1-3), basal endite with 4 stiff setae (4-7). Seven long soft setae of subequal size on limb corm posteriorly. Gnathobase weakly demarcated from basal endite, distal armature with 4 setae (Fig. 7H 1-4). Nine setae in filter plate.

Limb IV with pre-epipodite (Fig. 7I pep) epipodite large, ovoid, bearing a finger-like projection (Fig. 7I epp). Exopodite oval, with two distal, relatively long, bisegmented setae of unequal size, armed by short setules (Fig. 7I ext 1-2), other six setae feathered bilaterally by very long setules (Fig. 7I ext 3-8). Marginally on inner limb face, a row of four stiff anterior setae (Fig. 7I 1-4). Posteriorly, five soft setae with subequal length. Distal armature of gnathobase with 4 members (Fig. 7J 1-4). One of them a long, bisegmented seta, densely feathered in distal part (Fig. 7J 2), two others small (Fig. 7J 3-4), a large, bottleshaped sensillum (Fig. 7J 1) is the fourth member of gnathobasic armature (similarly to limb III). Filter plate IV with 9 setae, middle ones longer than marginal ones.

Limb V with pre-epipodite as a setulated hillock; epipodite with a finger-like projection (Fig. 7K). Exopodite very large, with four short distal (Fig. 7K 1-4) and three large lateral (Fig. 7K 5-7) setae. Inner portion of limb (Fig. 7K ilp) with a protruding flap-like distal projection, fringed by long setules. Three marginal setae on inner face of limb, distal member slightly protruding behind distal endopodite projection, a sensillum near basalmost seta. Distal armature of gnathobase with two hooks (Fig. 7L). Filter plate with 8 setae.

Limb VI triangular-shaped, with epipodite bearing a long finger-like projection and a row of setules somewhat distal to it; its inner margin setulated (Fig. 7M).

Ephippial female, male: unknown.

Length: parthenogenetic female; 0.73-2.27 mm.

Differential diagnosis: this is an E. lamellatus-like taxon with i) body of the parthenogenetic female compressed laterally and with a median keel on the dorsum of the carapace starting on the head shield just posteriorly to the head pore region; ii) dorsal head pores located on a transverse fold in the posterior portion of head shield, with a posterior indentation; iii) a single midgut loop. There are only three species with such a combination of characters: E. lamellatus (O.F. Müller, 1776), E. microdontus Frey, 1978, and E. freyi sp.nov. The latter could be easily differentiated from the two other species by a very strong indentation (with depth larger than head pore diameter) posterior to the head pores.

Previously, E. lamellatus and E. microdontus were assigned by Frey $(1975,1978)$ to the subgenus Eurycercus sensu stricto (s.str.), containing only two taxa and separated from the subgenus E. (Bullatifrons) Frey, 1975. Recent morphological and genetic analysis do not support separation of the latter from the former (Bekker, 2011; Bekker et al., 2012). The lamellatus-like taxa (lamellatus + microdontus) do not form a monophyletic group within the subgenus Eurycercus s.str. in our new understanding (including the subgenera Eurycercus s.str. and $E$. (Bullatifrons) sensu Frey, 1975). E. freyi sp.nov. seems to be the closest relative of $E$. lamellatus, a small clade that is supported by two synapomorphies: i) the rostrum is long; ii) the spine situated on the proximal segment of the exopod of antenna II is longer than the second segment, in contrast to E. microdontus. E. freyi sp.nov. does not seem to be a primitive taxon. In contrast, it is the closest congener of E. lamellatus, a widespread Palaearctic taxon. We could regard $E$. freyi sp.nov. as a relict of the lamellatus-group, though a younger dispersal scenario of the former in South Africa seems to be preferable.

Comments: this species was recorded for the first time by Harding (1961) as E. lamellatus. Subsequently Frey (1993) determined it as E. (Eurycercus) sp., doubting its identity as E. lamellatus. Smirnov (2008) included it in his South African checklist.

Distribution: E. freyi sp.nov. can be considered an endemic of the Western Cape province, Republic of South Africa (Tab. 2).

\section{Patterns of distribution of endemic cladocerans in South Africa}

From the analysis of the samples, the cladoceran endemics in the region can be roughly divided into three groups (Tab. 1; Figs. 8 and 9): i) species restricted to mountain localities $(>1000 \mathrm{~m}$ asl) in the eastern portion of Southern Africa (e.g., Drakensberg mountains) (Fig. 8B): Alona natalensis, Ovalona meridionalis, Pleuroxus carolinae, Dumontiellus africanus, Ilyocryptus martensi; ii) species only known from the Western Cape (Fig. 8C and 8D): Eurycercus freyi sp.nov., Alona capensis, Alona striolata, Leydigia microps, Ilyocryptus africanus, Macrothrix sarsi, Ceriodaphnia producta; iii) species widely distributed in Southern Africa both in the mountains and the lowlands, hitherto unreported from the rest of the continent (Fig. 8A): Leydigia propinqua, Leydigia macrodonta, Tretocephala colletti. 


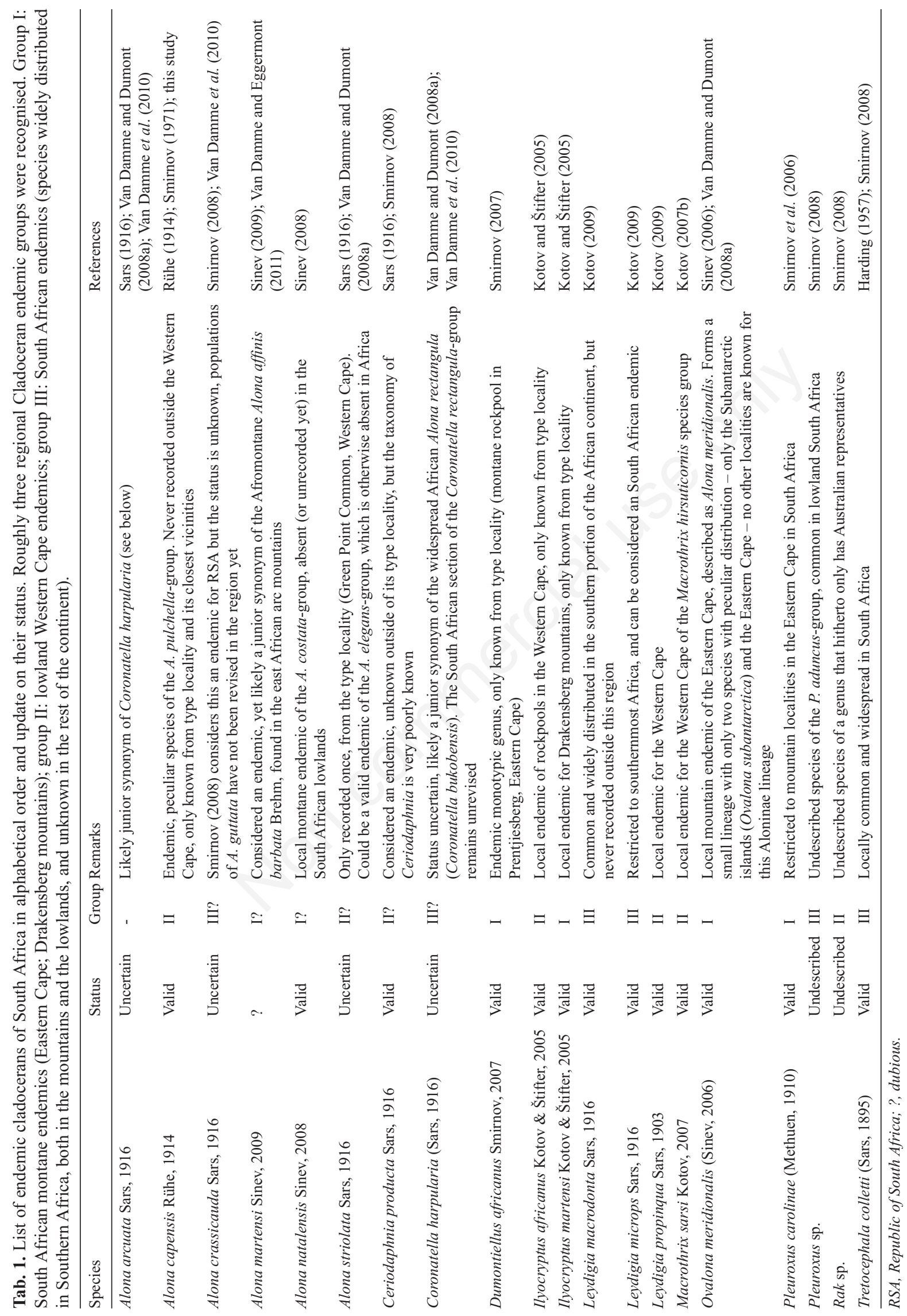




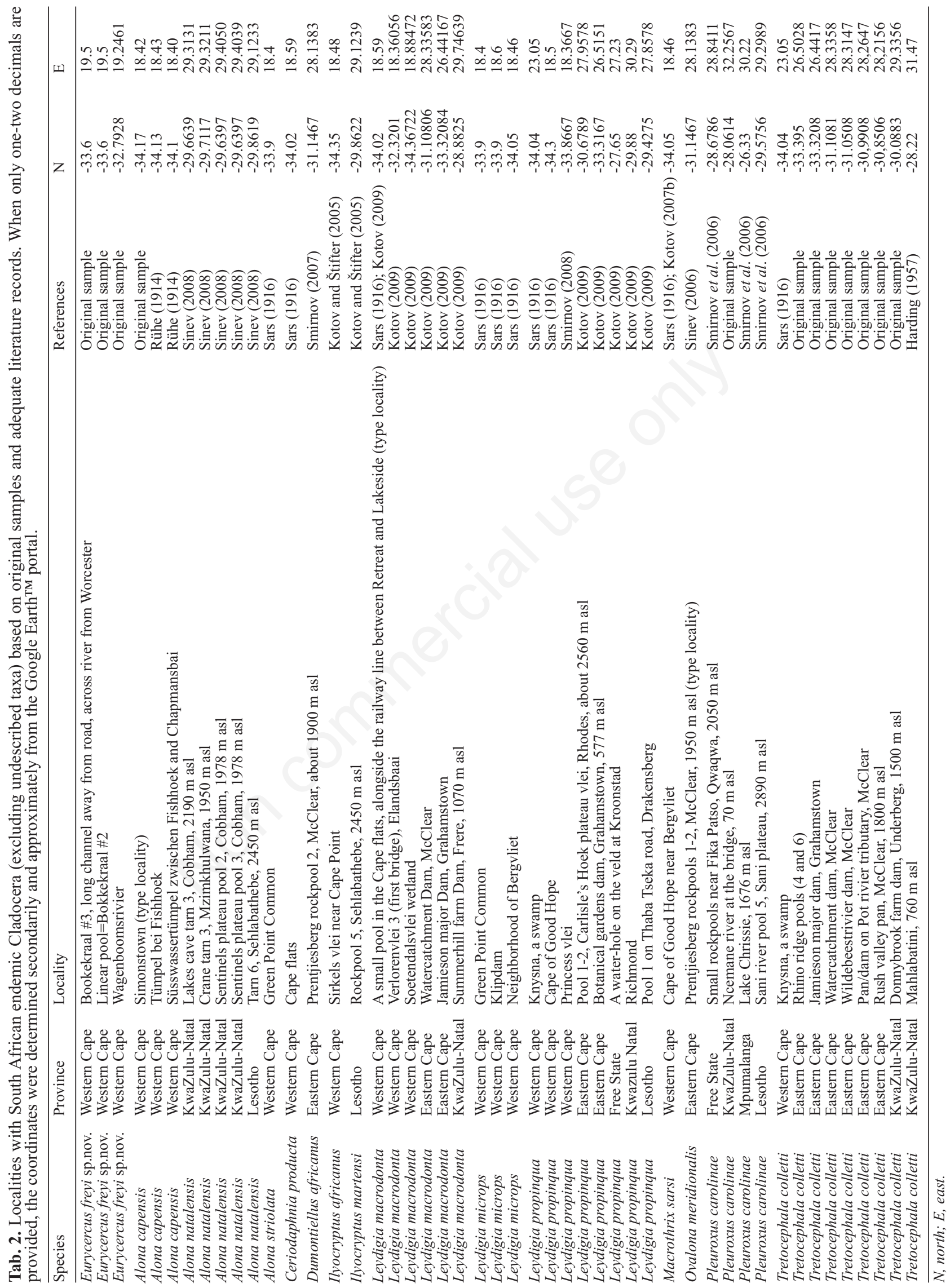




\section{DISCUSSION}

\section{Taxonomical efforts}

Frey (1993), Korovchinsky (2006) and Smirnov (2008) noted that South Africa harbours few endemics in the Cladocera. However, lower endemism in South Africa (Korovchinsky, 2006) can be attributed to an insufficient level of study, confirmed by recent findings (Kotov 2007b, 2009; Sinev, 2008, 2009; this study). Segers and De Smet (2008) also concluded that there are few known rotifer endemics in the Cape region, but that this is probably due to the absence of data, rather than being a fact (H. Segers, personal communication).
We demonstrate here (once again) that there is still a number of unknown endemic taxa found in South Africa, whose right assignment depends on taxonomical efforts. We need to compare the South African populations of many taxa (in reality, each taxon) with populations from other regions (e.g., Daphnia; see below). Our description of Eurycercus freyi sp.nov. demonstrates that in some cases it is relatively easy to find useful diagnostic characters (with taxonomical training) that reflect local divergence. It makes more sense to conclude on the status of specific populations (from South Africa or from any other region in the world) after a global revision of the genus under consideration, as recently shown for Eurycercus
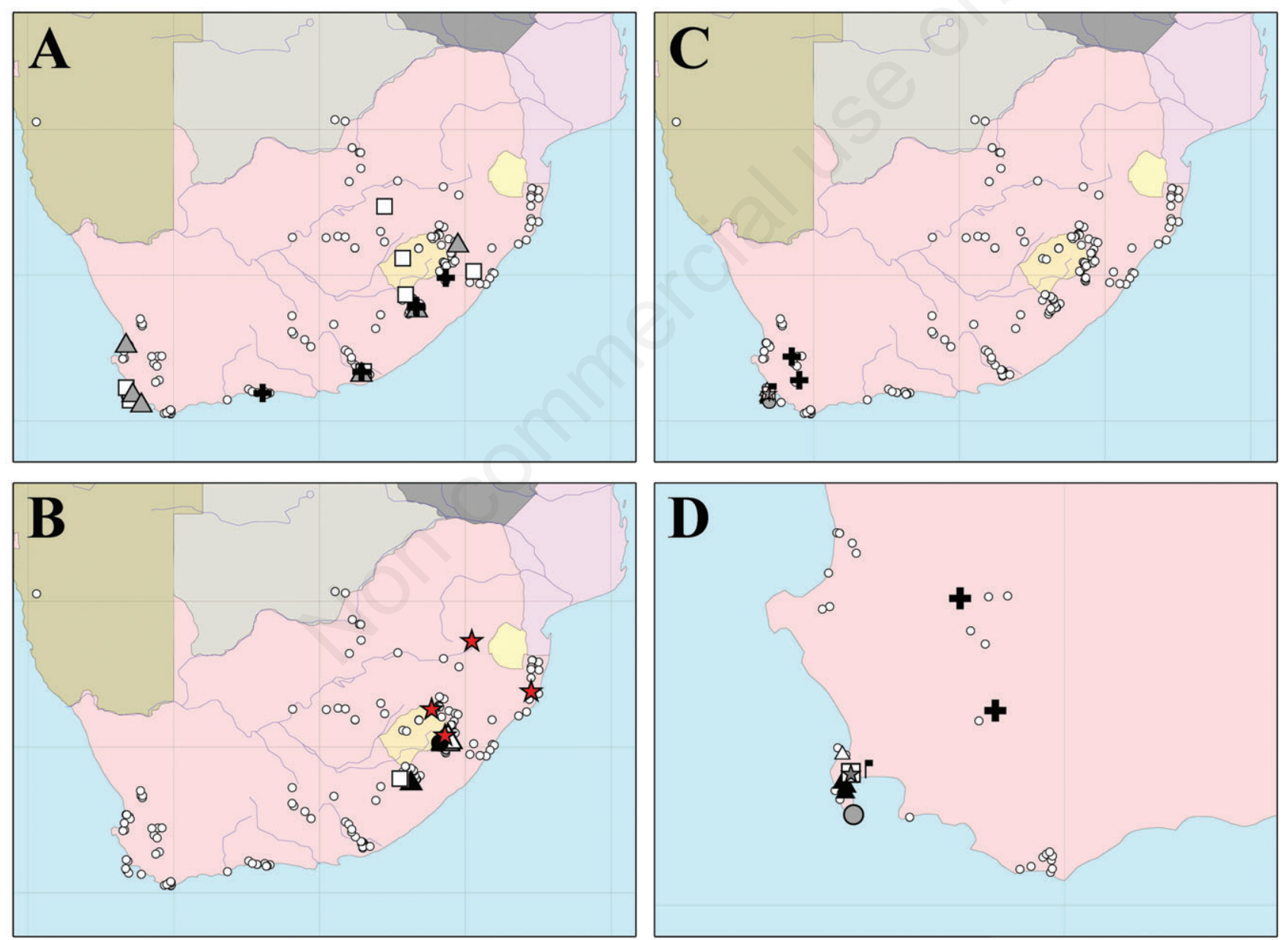

Fig. 8. Distributional maps of some South African endemics. In all maps, empty circles mark sampling points where cladocerans were collected, i.e. those published by Smirnov (2008). A, endemics of South Africa, widely distributed in the region: Leydigia propinqua (empty squares), Leydigia macrodonta (grey triangles), Tretocephala colletti (black crosses). B, endemics of the Drakensberg mountains: Alona natalensis (empty triangles), Ovalona meridionalis (black triangles), Pleuroxus carolinae (stars), Dumontiellus africanus (open squares), Ilyocryptus martensi (black circle). C-D, endemics of Western Cape lowlands: Alona capensis (black triangles), Alona striolata (empty triangle), Leydigia microps (empty square), Eurycercus freyi sp.nov. (black crosses), Ilyocryptus africanus (grey circle), Macrothrix sarsi (grey stars), Ceriodaphnia producta (black flag); D, enlargement of the farthest southwest part of the Western Cape lowlands (C). 
(Bekker, 2011; Bekker et al., 2012) or Leydigia (Kotov, 2009) and assess the morphology and speciation in context. As the diversity of the Cladocera is considered three to four times higher than recently accepted (Adamowicz and Purvis, 2005; Forró et al., 2008), more endemics can certainly be expected. All species hitherto recorded and described from the region, result from samples collected during sporadic visits in the region by a few researchers, who were mostly looking for other groups than Cladocera. Intense surveys specifically aimed at both the planktonic as well as benthic representatives of the group, in rivers and lakes of the lowlands and mountain areas (Cape Fold belt, Drakensberg mountains, etc.), and in unusual habitats such as temporary pools and swamps, will undoubtedly reveal more, as the region is likely to harbour a higher diversity of endemics than we currently assume. In order to assess aquatic diversity, redescriptions of poorly known species (e.g., A. capensis) are as valuable as the description of new taxa, though often considered as less important. In Chydoridae and particularly in the Aloninae, revisions and redescriptions are leading to increased taxonomical stability (Van Damme et al., 2010). Without an understanding of the existing diversity and collections, interpretation of cryptic species and delineation of new species are impossible.

The Chydoridae of South Africa nearly all need revi-

\section{Endemism in the South African Cladocera}

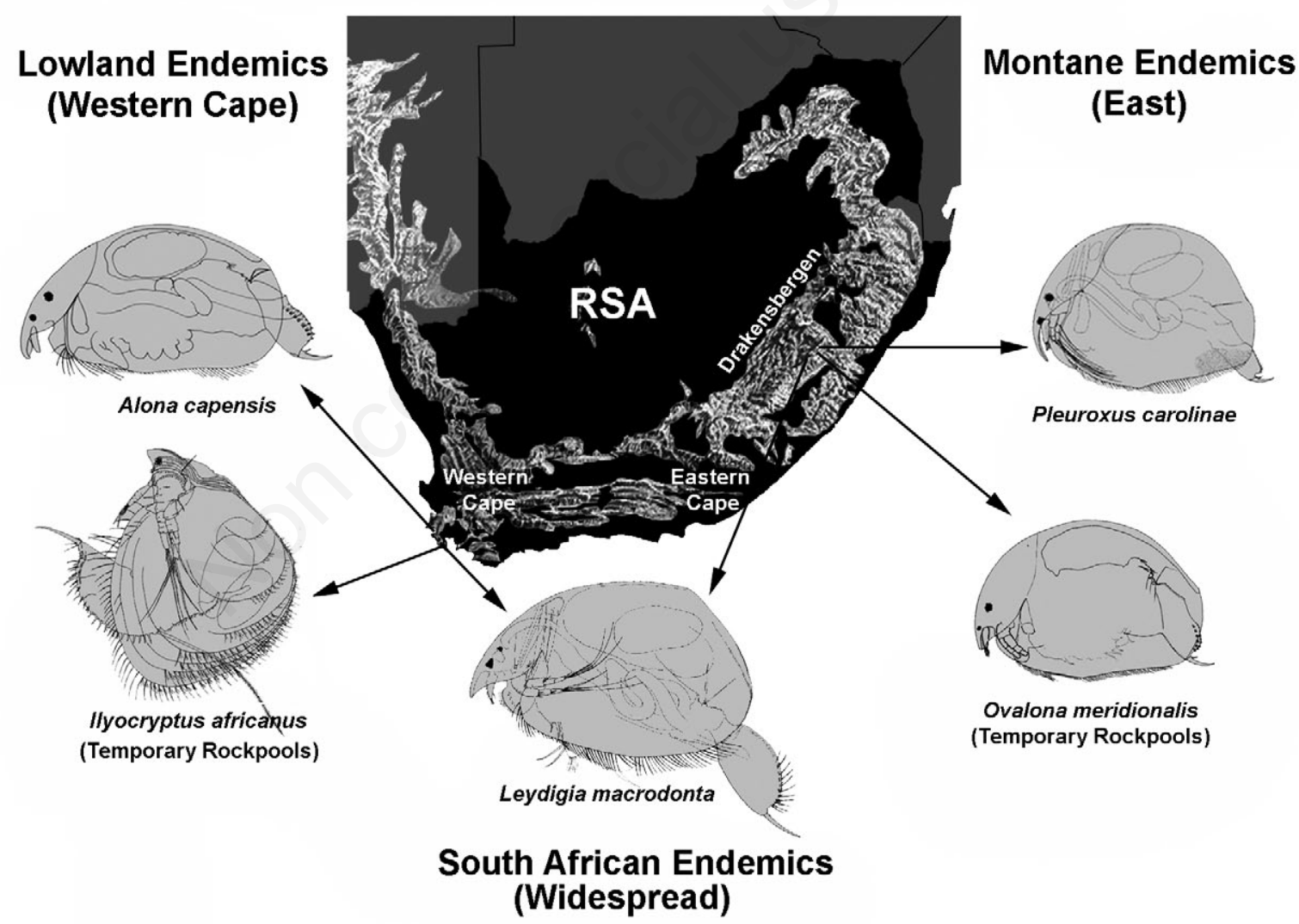

Fig. 9. Cladocera endemism in the Republic of South Africa and Lesotho. At present, known Cladocera endemics of South Africa (and Lesotho) comprise montane endemics in the East (e.g., P. carolinae and O. meridionalis in the Drakensberg mountains), lowland endemics of the Western Cape (e.g., A. capensis and I. africanus), and widespread South African endemics (e.g., L. macrodonta). Temporary rockpools form an important habitat for local cladoceran speciation, both in the mountain- and lowland areas: I. africanus and $O$. meridionalis are examples of rockpool species. Much of the country remains unstudied for Cladocera, such as the mountain areas in the South and West (e.g., Cape Fold belt), or lowlands of the northern Cape. Drawings of endemic species are from Kotov (2009; L. macrodonta), Kotov and Štifter (2005; I. africanus), Smirnov et al. (2006; P. carolinae), Sinev (2006; O. meridionalis), and this study (KVD; A. capensis). 
sion, despite the fact that currently this is one of the better studied anomopod families in the region. In the A. guttatagroup, the status of the South African Alona crassicauda Sars, 1916 remains unresolved (Van Damme et al., 2010) and its identity should be tested against other populations in Africa: some are morphologically identical to the European A. guttata (Van Damme and Eggermont, 2011). A. striolata Sars, 1916 of the A. elegans-group may actually be a true Cape endemic of temporary pools. No other records of this lineage are known from Africa (Van Damme and Dumont, 2008a). The montane A. martensi Sinev, 2009 (A. affinis-group) from the Drakensberg mountains, is likely a synonym of $A$. barbata Brehm, 1935 which occurs in the east African mountains (Van Damme and Eggermont, 2011). We are also unclear about the identity of the lowland A. affinis- or A. intermedia populations in the Cape, which were reported about a century ago by Sars (1916). The South African Coronatella species form another problematic group containing several names (A. bukobensis, A. harpularia, A. arcuata in Sars, 1916), and the synonymies and the relation to $C$. rectangula (former $A$. rectangula) are confusing (Van Damme and Dumont, 2008a; Van Damme et al., 2010). The status of the South African Karualona is unknown too and it is unlikely that $K$. karua occurs here (hence $K$. cf. karua in Smirnov, 2008), being an Australian species. In chydorid genera Alonella, Acroperus, Chydorus, Camptocercus, Leberis, Disparalona, Pleuroxus, etc., most of the detailed work for the South African populations remains to be done. It is worth tackling the species one by one. After our redescription of $A$. capensis, we found that it does not display an array of primitive characters, but instead shows a significant isolation within its lineage. Of all cladoceran species-level endemics in Southern Africa, $A$. capensis may be considered as one of the more divergent. It is a small species reported a century ago, which nobody remembers, in a region underestimated in Cladocera richness, and which testifies to how attention to taxonomical problems brings us a step closer to interpreting species richness and biodiversity in the region.

For other Cladocera (e.g., the Ctenopoda) much remains to be done. In the Macrothricidae and Ilyocryptidae, at least some endemics are known (see further), but the South African Moinidae remain unstudied. At this stage we are not able to accurately assess the taxa Macrothrix capensis or Moina tenuicornis, which are discussed by Sars (1916) and appear both in Australia (including Tasmania) and South Africa (Smirnov, 1976, 1992, 2008). An independent status of the populations from the different continents is likely, which means that M. capensis s.str. can be considered as an endemic of South Africa (where it is widely distributed), while Moina cf. tenuicornis could be a separate (new) species.

The number of endemic taxa described from the region is likely to increase in the future and the daphniids are definitely good candidates. The genus Ceriodaphnia Dana, 1853 has received little attention of cladoceran taxonomists during the last decades. Smirnov (2008) listed Ceriodaphnia species that were described from the Palaearctic, as well as general circumtropical names for South Africa, which seems unrealistic. Endemics do occur in the genus, e.g., we can regard C. producta as a clear endemic of the Cape. We believe that more endemics will be added in the future, keeping the increasing evidence in mind that the Ceriodaphnia cornuta-rigaudi-complex is actually a series of species (Berner, 1985). The same rationale can be applied to the genus Simocephalus Schoedler, 1858. Orlova-Bienkowskaja (2001) only had limited material from South Africa and was unable to properly evaluate the status of the local species, i.e. Simocephalus capensis Sars, 1895 , which is most probably a valid taxon. Unfortunately, the revision of this genus has now slowed down and stopped. Scapholeberis has not received focused attention in the region so far. However, of all South African daphniid genera, the situation is most complex for Daphnia itself.

\section{Neglected South African taxa: the example of Daphnia}

Daphnia is a likely candidate to contain endemic South African Cladocera species in the future (Fig. 10). In a recent revision of the genus, Benzie (2005) ignored the South African Daphnia (Smirnov, 2008). For example, Daphnia hodgsoni Sars, 1916 and D. coronata Sars, 1916 were both listed by Benzie (2005) as junior synonyms of D. dolichocephala Sars, 1895, whereas Daphnia tenuispina Sars, 1916 is included as a junior synonym of D. obtusa Kurz, 1874. The action of sinking the South African taxon D. tenuispina into D. obtusa, which is a strictly western Palaearctic species, is highly questionable (Kotov and Taylor, 2010). Some of the South African species inquirendae in Daphnia are considered valid by several authors, i.e., D. dolichocephala Sars, 1895, D. propinqua Sars, 1895, D. gibba Methuen, 1910 and D. coronata Sars, 1916 (Wagler, 1936; Glagolev, 1986; Hamer and Rayner, 1996; Kořínek, 2002). Whether $D$. coronata (Fig. 10) is valid or not, will depend on future revisions. Its main diagnostic character, the corona or crown of thorns (Sars, 1916; Fig. 10), is an inducible defense (Petrusek et al., 2008). D. dolichocephala and D. cf. gibba are not restricted to South Africa, but extend up to Kenya (Mergeay et al., 2005), whereas D. propinqua, $D$. coronata and D. tenuispina have not been reported more north. Our knowledge about the exact distribution and even our definition of the latter taxa is limited, yet these forgotten names could well shelter true endemics of Southern Africa.

There is also a number of Palaearctic biogeographical elements in the Cladocera of South Africa (Smirnov, 
2008), several of which were reported from other areas in the African continent. In total, Smirnov (2008) lists thirteen Daphnia species from South Africa, among which populations attributed to widespread Palaearctic taxa, like $D$. atkinsoni, D. curvirostris, D. galeata, D. pulex, D. magna, D. obtusa, D. laevis, D. lumholtzi and D. similis.
The true status and the local diversity of most of these populations remain unclear. In fact, the situation of Daphnia in Africa is highly complex and cannot be generalised. Each taxon presents a different case and morphology is often insufficient to trace the origins of Daphnia populations. Molecular analysis suggested that the current pop-

The Frexh-water Entomostraca of Cape Province (Union of South Africa).-By G. O. Sars. Part I: Cladocera. With $1: 3$ plates.

FAM. DAl'HNIIDAE.

Gen. 1. DAPHNIA, O. Fr. Müller.
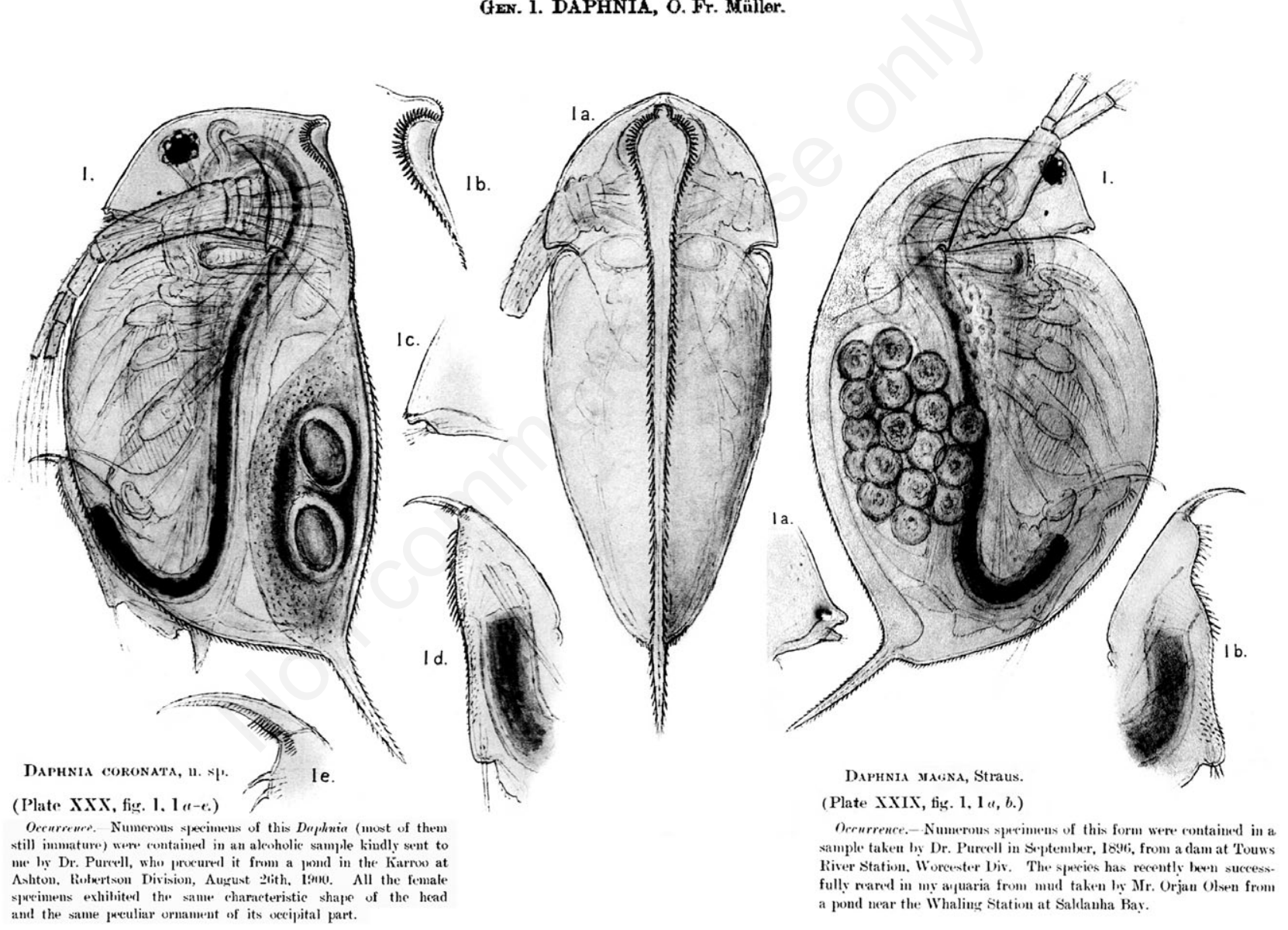

Fig. 10. Georg Ossian Sars, a pioneer in crustacean research, provided the first detailed accounts on the South African freshwater Cladocera (from the Cape province), most of which he obtained by incubating dry mud samples containing ephippia (Van Damme and Dumont, 2010). The status of several South African taxa that were described or mentioned by Sars (1916) remains to be resolved. Daphnia records require critical revision. Daphnia coronata Sars, 1916 (shown here on the left in lateral view with postabdomen and in the middle in dorsal view), is considered by some authors as a junior synonym of $D$. dolichocephala Sars, 1895, by others as a valid species (see text). The taxonomical status of this species inquirenda is complicated by the fact that the main diagnostic feature, the crown of thorns (corona), depicted beautifully by Sars (1916) (dorsal view in central drawing), is an inducible defence (Petrusek et al., 2008). To delineate this taxon and solve its status, morphological and molecular revision of related African taxa such as D. dolichocephala Sars, 1895 and D. hodgsoni Sars, 1916 is needed as well. Daphnia magna Straus, 1820 (lateral view and postabdomen on the right), on the other hand, could be a Palaearctic biogeographical element in the South African Cladocera fauna and/or an isolated cryptic species, or even a recent human-induced invader. All drawings after Sars (1916), figure by KVD. 
ulations of $D$. pulex on the African continent actually are pulex $\mathrm{x}$ pulicaria hybrids that have been introduced and expanded throughout the continent over a period of ca. 80 years (yrs), belonging to a north American haplotype (Mergeay et al., 2006, Crease et al., 2012). Hence, the current South African D. pulex is most likely an exotic hybrid that has replaced a native D. pulex, which was closer to the European populations (Mergeay et al., 2006). African D. obtusa populations, in contrast, reveal a truly cryptic diversity. Previously considered as belonging to the same species, montane endemics like D. izpovdala in the Ethiopian Bale mountains (Kotov and Taylor, 2010) are morphologically and genetically different from the European D. obtusa, and morphologically different from the single population of $D$. cf. obtusa in the nearby Rwenzori mountains (Van Damme and Eggermont, 2011). For the remaining Palaearctic Daphnia species in South Africa, like D. magna (Sars, 1916; Fig. 10), which is found also in East Africa (Löffler, 1968, Mergeay et al., 2005), wide molecular surveys (De Gelas and De Meester, 2005) have not taken the South African populations into account, therefore we cannot speculate on their origin. Adamowicz et al. (2009) also noted that In particular, data are lacking to a large degree for the African and Asian faunas in their Daphnia phylogeny. From palaeoendemic to exotic species, several scenarios are possible for the Palaearctic Daphnia in South Africa. For most Daphnia species, the morphology remains to be critically revised (Fig. 10).

\section{Note on biogeographical affinities}

No detailed studies have been carried out (yet) to explore the affinities of the South African endemic species as a group. Biogeographical affinities in the South African endemic Cladocera might suggest ancient origins of several species, yet most of what we currently know is based on the phenotype only, and a lot of molecular work remains to be done. There are several biogeographical peculiarities that are worth mentioning here, among which disjunctions between Australia or the Palaearctic and South Africa.

Regarding Subantarctic islands, the endemic Ovalona meridionalis of the Drakensberg mountains (Sinev, 2006; Fig. 9) belongs to a small lineage in the Aloninae of just two species - its sibling species is Ovalona subantarctica, distributed only in the Subantarctic islands (Van Damme and Dumont, 2008a). In Pleuroxus, P. carolinae shows affinities with the Subantarctic chydorid endemic $P$. wittsteini (Smirnov et al., 2006).

In Australia, closest siblings (two species) of a yet undescribed South African Rak Smirnov and Timms, 1983 from an unpublished note by Frey (Smirnov, 2008) are found. Two other potential endemics of South Africa, Macrothrix capensis Sars, 1916 and Moina cf. tenuicornis
Sars, 1896, are parts of species complexes that are present only in South Africa and in Australia (Smirnov, 1976, 1992). These taxa need to be revised.

As far as the Palaearctic is concerned, a Palaearctic link is clear in Tretocephala, a conspicuous genus with only two species, of which one is confined to South Africa (T. colletti), the second is widespread in the Palaearctic (T. ambigua). In Eurycercus, the link between E. freyi n.sp. and E. lamellatus can also be seen as a South African-Palaearctic link. In both cases, populations from the Cape seem to have been isolated from Palaearctic populations sufficiently to recognise morphological divergence to species level.

The other well-delineated South African endemics belong to widespread lineages. In the case of Western Cape endemic A. capensis, no close siblings are known, as is the case for the endemic genus from the Drakensberg mountains in the East, Dumontiellus. Their morphological divergence indicates strong isolation.

\section{South Africa as a centre of cladoceran endemism: the importance of mountains and rockpools}

Van Damme and Dumont (2009) proposed South Africa as a centre of cladoceran endemism in the African continent, which harbours a rich diversity of endemic littoral cladocerans. Especially the plateaus and granite outcrops such as the Drakensberg seem to harbour specific chydorid endemics. Ancient afromontane environments have a strong insular character within the continent and may reveal more surprises (Van Damme and Dumont, 2009). High mountain areas in the tropics-subtropics, because of their insular character, are zones of cladoceran endemism (Kotov and Taylor, 2010; Kotov et al., 2010; Van Damme and Eggermont, 2011). Therefore, endemics were (and are) expected among the freshwater branchiopods in the South African mountains. Unfortunately, we know only about a few cladoceran species in the eastern portions of South African mountains, and virtually nothing of the southern and western parts of this elevated area. Even though the semi-arid area in the west and central areas of South Africa has hundreds of vleis, temporary pools and pans (Reid et al., 2000), we know little of the Cladocera they harbour.

In larger branchiopods of Southern Africa, montane isolation and radiation have been linked with the persistence of temporary rock pools throughout the ages, especially in the short-lived specialists in the genus Branchipodopsis, which radiated in the Drakensberg mountains (Brendonck and Riddoch, 1997; Hamer and Appleton, 1996; Jocqué et al., 2010; Brendonck et al., 2000). However, Eurycercus freyi sp.nov., Alona capensis, Leydigia microps, Ilyocryptus africanus, Macrothrix sarsi and Ceriodaphnia producta are lowland endemics of the Western Cape, never recorded outside this small re- 
gion. We can therefore state that micro-branchiopod endemism in the region is not restricted to the mountains alone. The role of short-lived temporary freshwater pools (at low and at high altitudes) in speciation of the southern African Cladocera, deserves close attention. Endemism in temporary freshwater pools (not only rockpools) of the Western Cape is known for ephemeral calanoid copepods in low-lying areas (Reid et al., 2000). In the Western Cape as well as in the Drakensbergen, for the genus Ilyocryptus, Kotov and Štifter (2005) described the first representatives in the family Ilyocryptidae that have ever been found in temporary freshwater rockpools, an ignored habitat in limnological surveys. I. martensi was found at $2450 \mathrm{~m}$ altitude in Lesotho (East), and I. africanus at $100 \mathrm{~m}$ altitude in the Western Cape (Kotov and Štifter, 2005). It is a remarkable fact that both the aforementioned endemic ilyocryptids are members of a pan-continentally distributed crown-group of the genus (Kotov and Elías-Gutiérrez, 2009). There are doubts on their origins: they could not be regarded as primitive, but assuming that the crowngroup is very old (=possibly even as far as the Mesozoic), they could be regarded as descendants of a proto-taxon with a pan-continental distributional area. The same is true for Macrothrix sarsi, an endemic member of the hirsuticornis-group (Kotov, 2007b). The endemic genus Dumontiellus Smirnov, 2007 is another example of a South African rock-pool endemic from high altitudes, and so is Pleuroxus carolinae (Smirnov, 2007; Smirnov et al., 2006). A. striolata Sars, 1916 could also be found among the ephemeral endemics, as the A. elegans-complex to which it belongs typically contains specialists of shortlived pools (Van Damme and Dumont, 2008a). The dynamic coexistence/succession of Cladocera with Anostraca, for example between Leberis sp. and Branchipodopsis in temporary rockpools in Botswana (Jocqué et al., 2007), illustrates local adaptation to these ecosystems.

The general biota of the south-western extremity of Africa is very specific for this continent and rich of endemics. In recent revisions based on plants and vertebrates, Southern Africa is its own biogeographical region (Linder et al., 2012). Many authors have tried to explain this phenomenon. Within this region, the Cape peninsula is characterised physiographically by high topographical heterogeneity and a climate with very long and steep gradients in annual rainfall (Cowling et al., 1996; Linder et $a l ., 2010)$. The Cape peninsula landscape is a part of the Cape Fold belt, an L-shaped band at the southwestern corner of Africa of sandstone mountains alternating with plains formed by softer shales; both appeared between 450 and 340 million years ago (Mya) (Deacon et al., 1992). A coastal portion of the Western Cape lowlands was inundated by transgressions during the mid-Miocene (15 Myr) and the early-mid-Pliocene (4 Mya) (Hendey,
1983; Cowling and Holmes, 1992), but the Cape Fold belt landscapes are ancient, having changed little during the past $60 \mathrm{Mya}$; they have been spared from extreme climatic conditions (including glaciation) during this period (Harrison, 1965b; Deacon et al., 1983, 1992). The recent Mediterranean-type climate was established some time after the beginning of the Pliocene (Wishart and Day, 2002). Together with high endemism, this region is a centre of recent plant diversification which began approximately $7 \pm 8 M y r$ ago, coincident with extensive aridification caused by changes in ocean currents (Richardson et al., 2001). The terrestrial flora of the Cape area is uniquely species-rich and exhibits exceptionally high levels of endemism. This south-western corner of Africa is regarded as the Cape floral kingdom, different in the understanding of different botanists (Born et al., 2007; Linder et al., 2010). Even in such a small area, there are small-sized hotspots of micro-endemism such as Table mountain (Picker and Samways, 1996), which remains poorly investigated for Cladocera. The endemics from this region are usually regarded as relicts (Picker and Samways, 1996).

The Western Cape is traditionally regarded as a harbour of endemics in freshwater invertebrates as well (see Introduction; Wishart and Day, 2002; Cumberlidge and Daniels, 2007; Korovchinsky, 2006). These are usually regarded as old elements, palaeo-endemics showing their greatest development in Western Cape province, largely restricted to refugial regions, mainly montane (Harrison, 1965a). Harrison (1965b) wrote that some non-tropical, i.e. cold stenothermal, taxa typically derived from glacial border taxa. Palaearctic elements are present in Africa on high altitude cold-water islands, so-called Löffler islands, the East African sky arc allowing a cold-water corridor in the Eastern rift (Van Damme and Eggermont, 2011). We do not know to which extent the Palaearctic elements in South Africa (Smirnov, 2008) are truly Palaearctic. For example, Hart and Dumont (2005) found a single specimen of the Holarctic Lathonura sp. (Macrothricidae) in the Okavango delta, but it is unclear whether this is a separate South African endemic, a Palaearctic relict, or a case of human introduction. This is actually true for most South African Palaearctic elements right now (see earlier on Daphnia).

Many authors correlated South African endemism even with earlier events, i.e., they regarded the relicts as descending from the southern temperate Gondwana fauna, but recent data also suggest a recent speciation in freshwater invertebrates (about 3-4 Mya) (Wishart and Day, 2002). Therefore, the age of the appearance of endemics in the Cape region is unknown and, presumably, could be very different and associated with different biogeographic events over a huge time span, from Gondwana disruption to Pliocene/Pleistocene aridification. 
Cladoceran taxa of different rank are very old (Frey, 1987; Kotov, 2007a; Kotov and Taylor, 2011) and the South African endemics are regarded as ancient relicts (Korovchinsky, 2006). However, we found that the two taxa under consideration do not have particularly primitive phenotypes within their lineages. Most probably, they represent isolated lineages that secondarily adapted to local conditions. The existence of antique lineages does not contradict with the possibility of recent speciation and adaptation. For a better understanding of timing of endemic differentiation in the Western Cape or the Drakensberg mountains, we would benefit from accurate molecular clock calculations based on phylogenetic trees for those genera with endemics in South Africa. This is a task for the future. Unfortunately, the cytochrome oxidase I gene (COI) tree for Eurycercus (Bekker et al., 2012) is not acceptable for such calculations, due to significant differences in the branch lengths (other genes need to be applied). For Daphnia, where more markers have been sequenced and more comparable molecular data is available, unfortunately no such studies have been carried out for the South African endemics.

Many lowland aquatic habitats in South Africa are brackish, and at conductivity $>4.6 \mathrm{mScm}^{-1}$ the number of taxa per site declines rather abruptly (Frey, 1993). Organic and inorganic pollution (i.e. due to open-pit mining) and water body salinisation resulting from intense agriculture, are major harmful threats in African aquatic ecosystems (Clausnitzer et al., 2012). Hamer and Brendonck (1997) discussed the need for conservation of the larger branchiopods. In analogy, the endemic copepods from lowland temporary pools in the Western Cape are considered highly vulnerable, as their habitat is under sincere human pressure, with an extinction of endemics as a logical result (Reid et al., 2000). The situation in the Cladocera is not different. It is now clear that the local cladoceran fauna in South Africa is rich and unique and deserves special attention, as well as protection.

\section{CONCLUSIONS}

We can confirm South Africa as a centre of endemism for the Cladocera. The region remains insufficiently studied and a number of earlier described taxa as well as Palaearctic populations require revision (e.g., Daphnia, Alona). Future surveys and taxonomical revisions will no doubt reveal higher local diversity and a better view on the patterns of endemism. Temporary freshwater pools can be considered as an important habitat for Cladocera speciation in South Africa, largely ignored during zooplankton sampling campaigns. Again we can state that closer attention to taxonomy in this (and any) region allows a better interpretation of local endemism and patterns of distribution in the cladocerans and that such work is needed. Biogeographical links between the South
African endemic Cladocera and their sibling species (e.g., with Sub-Antarcic islands, Australia, Palaearctic), should be further explored.

The Southern African endemic Cladocera can be roughly divided into three groups based on our current taxonomical knowledge: i) montane endemics of the East (e.g., Drakensberg mountains); ii) local endemics of the Western Cape lowlands, and iii) South African endemics widely distributed in both mountain and lowland regions.

Alona capensis Rühe, 1914 is a valid, peculiar species. It belongs to the $A$. pulchella species complex, a lineage still housed in the lumping genus Alona Baird, 1843. A. capensis is only the second species of this group in the African continent (the other is A. cambouei) and appears to be a lowland Western Cape endemic. The species displays peculiar characters, yet the limb morphologies leave no doubt towards its affinities. Morphological divergence in postabdomen and body indicates a significant degree of isolation of this chydorid within its lineage ( $A$. pulchella-group).

Eurycercus freyi sp.nov. is a new taxon, earlier misidentified as E. lamellatus. The former seems to be the closest relative of the latter, but differs in a series of characters, first of all the morphology of the head pore area.

\section{ACKNOWLEDGMENTS}

We thank Prof. N.N. Smirnov (A.N. Severtsov Institute of Ecology and Evolution, Moscow) and Dr. G. Jones (University of Cape Town, South Africa) for numerous samples from South Africa, Dr. O. Coleman (ZMHU) for providing the type specimens of Alona capensis on loan.

A short-term visit of AAK to USNM was supported by awards from the Office of Fellowships, Smithsonian Institution, USA. AAK thanks Dr F.D. Ferrari, Dr J. Fornshell, Dr E. Fornshell, and Dr C. Walter for their hospitality and help during his stay at the Smithsonian, and L. Ward for providing the accession numbers for the new Eurycercus. The study is partly supported by the Russian Foundation for Basic Research (grants 12-04-00207-a and 12-04-90857-мол_рф_нр) and the Program of the Presidium of Russian Academy of Sciences Biodiversity: State and Dynamics (for EIB and AAK).

\section{DEDICATION}

This study is dedicated to Prof. Dr N.N. Smirnov (A.N. Severtsov Institute of Ecology and Evolution, Moscow) in honour of his contributions to the knowledge of the South African Cladocera.

\section{REFERENCES}

Adamowicz SJ, Petrusek A, Colbourne JK, Hebert PDN, Witt JDS, 2009. The scale of divergence: a phylogenetic appraisal of intercontinental allopatric speciation in a passively dis- 
persed freshwater zooplankton. Mol. Phylogenet. Evol. 50:423-436.

Adamowicz SJ, Purvis A, 2005. How many branchiopod crustacean species are there? Quantifying the components of underestimation. Global. Ecol. Biogeogr. 14:455-468.

Alonso M, 1996. [Crustacea, Branchiopoda. Fauna Iberica 7. Crustacea Branchiopoda]. [Book in Spanish]. Museo Nacional de Ciencias Naturales - Consejo Superior de Investigaciones Cientificas ed., Madrid: 486 pp.

Bekker EI, 2011. Morphological backgrounds of systematics of the family Eurycercidae Kurz, 1875 sensu Dumont et Silva-Briano, 1998 (Cladocera: Anomopoda). Biol. Bull. 38:557-568.

Bekker EI, Kotov AA, Taylor DJ, 2012. A revision of the subgenus Eurycercus (Eurycercus) Baird, 1843 emend. nov. (Cladocera: Eurycercidae) in the Holarctic with the description of a new species from Alaska. Zootaxa 3206:1-40.

Benzie JAH, 2005. The genus Daphnia (including Daphniopsis) (Anomopoda: Daphniidae). Kenobi Productions, Ghent and Backhuys Publ., Leiden: 376 pp.

Berner DB, 1985. Morphological differentiation among species in the Ceriodaphnia cornuta complex (Crustacea, Cladocera). Verh. Internat. Verein. Theor. Angew. Limnol. 22: 3099-3103.

Born J, Linder HP, Desmet P, 2007. The greater Cape Floristic Region. J. Biogeogr. 34:147-162.

Brendonck L, 1999. Conchostraca, p. 59-80. In: J.A. Day, B.A. Stewart, I.J. de Moor, and A.E. Louw (eds), Guides to the freshwater invertebrates of Southern Africa. Crustacea I: Notostraca, Anostraca, Conchostraca and Cladocera. South African Water Research Commission ed.

Brendonck L, Hamer ML, Riddoch BJ, Seaman MT, 2000. Branchipodopsis species - specialists of ephemeral rock pools. Afr. J. Aquat. Sci. 25:98-104.

Brendonck L, Riddoch J, 1997. The anostracans (Branchiopoda) of Botswana: morphology, distribution, diversity and endemicity. J. Crustacean Biol. 17:111-134.

Chiambeng GY, Dumont, HJ, 2005. The Branchiopoda (Crustacea: Anomopoda, Ctenopoda and Cyclesterida) of the rain forests of Cameroon, West Africa: low abundances, few endemics and a boreal-tropical disjunction. J. Biogeogr. 32:1611-1620.

Clausnitzer V, Dijkstra K-DB, Koch R, Boudot JP, Darwall WRT, Kipping J, Samraoui B, Samways MJ, Simaika JP, Suhling F, 2012. Focus on African freshwaters: hotspots of dragonfly diversity and conservation concern. Front. Ecol. Environ. 10:129-134.

Cowling RM, Holmes PM, 1992. Endemism and speciation in a lowland flora from the Cape Floristic Region. Biol. J. Linn. Soc. 47:367-383.

Cowling RM, MacDonalds IAW, Simmons MT, 1996. The Cape Peninsula, South Africa: physiographical, biological and historical background to an extraordinary hot-spot of biodiversity. Biol. Conserv. 5:527-550.

Crease TJ, Omilian AR, Costanzo KS, Taylor DJ, 2012. Transcontinental phylogeography of the Daphnia pulex species complex. PLoS ONE 7:e46620.

Crosetti D, Margaritora FG, 1985. Morphological, ecological and biological data for a better knowledge of Alona nuragica Margaritora (Cladocera). Crustaceana 49:268276.
Cumberlidge N, Daniels SR, 2007. A conservation assessment of the freshwater crabs of southern Africa (Brachyura: Potamonautidae). Afr. J. Ecol. 46:74-79.

Daday E von, 1910. [Untersuchungen über die SüsswasserMikrofauna Deutsch-Ostafrikas]. [Article in German]. Zoologica 59:1-316.

Deacon HJ, Hendey QB, Lambrechts JJN, 1983. Fynbos palaeoecology: a preliminary synthesis. CSIR National Scientific Programmes Unit ed., Pretoria: 227 pp.

Deacon HJ, Jury MR, Ellis F, 1992. Selective regime over time, p. 6-22. In: R.M. Cowling (ed.), The ecology of Fynbos: nutrients, fire and diversity. Oxford University Press.

De Gelas K, De Meester L, 2005. The phylogeography of Daphnia magna in Europe. Mol. Ecol. 14:753-764.

Dodson SI, Frey DG, 2001. Cladocera and other Branchiopoda, p. 849-913. In: J.H. Thorp and A.P. Covich (eds.), North American freshwater invertebrates. Academic Press.

Dumont HJ, 1981. Cladocera and free-living Copepoda from the Fouta Djalon and adjacent mountain areas in West Africa. Hydrobiologia 85:97-116.

Dumont HJ, 1994. On the diversity of the Cladocera in the tropics. Hydrobiologia 272:27-38.

Elías-Gutiérrrez M, Suárez-Morales E, Gutiérrez-Aguirre M, Silva-Briano M, Granados-Ramírez, JG, Garfias-Espejo T, 2008. [Cladocera y Copepoda de las aguas continentales de Mexico. Guia ilustrada]. Universidad Nacional Autónoma de México, México ed., Mexico City: 322 pp.

Elmoor-Loureiro LMA, 2000. Brazilian cladoceran studies: where do we stand? Nauplius 8:117-131.

Forró L, Korovchinsky NM, Kotov AA, Petrusek A, 2008. Global diversity of cladocerans (Cladocera; Crustacea) in freshwater. Hydrobiologia 595:177-184.

Frenzel P, Alonso M, 1988. Alona azorica sp. nov., a new chydorid (Cladocera) from the Western Palearctic. Arch. Hydrobiol. 112:449-465.

Frey DG, 1965. A new genus of Chydoridae (Cladocera). Int. Rev. Ges. Hydrobio. 50:153-168.

Frey DG, 1975. Subgeneric differentiation within Eurycercus (Cladocera, Chydoridae) and a new species from Northern Sweden. Hydrobiologia 46:263-300.

Frey DG, 1978. A new species of Eurycercus (Cladocera, Chydoridae) from the Southern United States. Tulane Stud. Zool. Bot. 20:1-25.

Frey DG, 1987. The taxonomy and biogeography of the Cladocera. Hydrobiologia 145:5-17.

Frey DG, 1993. The penetration of cladocerans into saline waters. Hydrobiologia 267:233-248.

Glagolev SM, 1986. [Morphology, systematics and geographic distribution of the cladoceran genus Daphnia from Eurasia]. [PhD Thesis in Russian]. IEMEZh Akad. Nauk SSSR ed., Moscow: 226 pp.

Gurney R, 1904. On a small collection of a freshwater Entomostraca from South Africa, p. 298-301. In: Proc. General Meetings for Scientific Business of the Zoological Society of London, Academic Press.

Hamer M, Appleton CC, 1996. The genus Branchipodopsis (Crustacea, Branchiopoda, Anostraca) in Southern Africa: morphology, distribution, relationships and the description of five new species. Ann. S. Afr. Mus. 104:311-377.

Hamer M, Brendonck L, 1997. Diversity, distribution and con- 
servation of Anostraca in Southern Africa. Hydrobiologia 359:1-12.

Hamer M, Rayner NA, 1996. A note on the unusual crustacean community of a temporary pool in the Northern Cape. S. Afr. J. Aquat. Sci. 22:100-104.

Harding JP, 1957. The South African Cladoceran Euryalona colletti (Sars) and another African species. Ann. S. Afr. Mus. 42:245-247.

Harding JP, 1961. Some South African Cladocera collected by Dr. A. D. Harrison. Ann. S. Afr. Mus. 46:35-46.

Harrison AD, 1965a. Geographical distribution of riverine invertebrates in Southern Africa. Arch. Hydrobiol. 61:387394.

Harrison AD, 1965b. River zonation in Southern Africa. Arch. Hydrobiol. 61:380-386.

Hart RC, Dumont HJ, 2005. An Holarctic taxon in the Ethiopian region - a first record of Lathonura (Crustacea: Cladocera: Macrothricidae) of the Okavango swamps of subtropical Africa. S. Afr. J. Aquat. Sci. 101:565-567.

Hendey QB, 1983. Palaeontology and palaeoecology of the fynbos region: an introduction, p. 100-115. In: H.J. Deacon, Q.B. Hendey, J.J.N. Lamprechts (eds.), Palaeoecology of the Fynbos landscape: a preliminary synthesis. South African National Scientfic Programmes Report, 75. Council for Scientific and Industrial Research ed.

Jenkin, PM, 1954. Report on the Percy Sladen expedition to some rift valley lakes in Kenya in 1929. VI. Cladocera from the rift valley lakes in Kenya. J. Nat. Hist. 13:137-160.

Jocqué M, Riddoch BJ, Brendonck L, 2007. Successional phases and species replacements in freshwater rock pools: towards a biological definition of ephemeral systems. Freshwater Biol. 52:1734-1744.

Jocqué M, Vanschoenwinkel B, Brendonck L, 2010. Freshwater rock pools: a review of habitat characteristics, faunal diversity and conservation value. Freshwater Biol. 55:1587-1602.

Johnson DS, 1953. On some Cladocera from South African muds. J. Nat. Hist. 6:923-928.

Karanovic I, 2012. Recent freshwater Ostracods of the world. Crustacea, Ostracoda, Podocopida. Springer, Amsterdam: 608 pp.

Kořínek V, 1984. Cladocera, p. 1-117. In: J.-J. Symoens (ed.), Hydrobiological survey of the lake Bangweulu Luapula river basin. Scientific results. Cercle hydrobiologique de Bruxelles ed.

Kořínek V, 2002. Cladocera, p. 69-122. In: C.H. Fernando (ed.), A guide to tropical freshwater zooplankton. Backhuys Publ.

Korovchinsky NM, 2004. [Cladocerans of the order Ctenopoda of the world fauna (morphology, systematics, ecology, biogeography)]. [Book in Russian]. KMK Press, Moscow: 410 pp.

Korovchinsky NM, 2006. The Cladocera (Crustacea: Branchiopoda) as a relict group. Zool. J. Linn. Soc. Lond. 147:109-124.

Kotov AA, 2007a. Jurassic Cladocera (Crustacea, Branchiopoda) with a description of an extinct Mesozoic order. J. Nat. Hist. 41:13-37.

Kotov AA, 2007b. Revision of the hirsuticornis-like species of Macrothrix Baird, 1843 (Cladocera: Anomopoda: Macrothricidae) from Subantarctic and temperate regions of the southern hemisphere. J. Nat. Hist. 41:2569-2620.

Kotov AA, 2009. A revision of Leydigia Kurz, 1875
(Anomopoda, Cladocera, Branchiopoda), and subgeneric differentiation within the genus. Zootaxa 2082:1-68.

Kotov AA, Elías-Gutiérrez M, 2009. A phylogenetic analysis of Ilyocryptus Sars, 1862 (Cladocera: Ilyocryptidae). Int. Rev. Hydrobiol. 94:208-225.

Kotov AA, Sinev AY, 2011. Cladocera (Crustacea, Branchiopoda) of the Zeya basin (Amurskaya Area, Russian Federation). 2. Descriptions of new taxa. Zool. Zh. 90:272-284.

Kotov AA, Sinev AY, Berrios VL, 2010. The Cladocera (Crustacea: Branchiopoda) of six high altitude water bodies in the North Chilean Andes, with discussion of Andean endemism. Zootaxa 2430:1-66.

Kotov AA, Štifter P, 2005. Notes on the genus Ilyocryptus Sars, 1862 (Cladocera: Anomopoda: Ilyocryptidae). 7. Two new species from South Africa, with first record of Ilyocryptus from rockpools. Arthropoda Selecta 14:219-228.

Kotov AA, Taylor DJ, 2010. A new African lineage of the Daphnia obtusa group (Cladocera: Daphniidae) disrupts continental vicariance patterns. J. Plankton Res. 32:937-949.

Kotov AA, Taylor DJ, 2011. Mesozoic fossils (>145 Mya) suggest the antiquity of the subgenera of Daphnia and their coevolution with chaoborid predators. BMC Evol. Biol. 11:129.

Linder HP, de Klerk HM, Born J, Burgess ND, Fjeldså J, Rahbek C, 2012. The partitioning of Africa: statistically defined biogeographical regions in sub-Saharan Africa. J. Biogeogr. 39:1189-1205.

Linder HP, Johnson SD, Kuhlmann M, Matthee CA, Nyffeler R, Swartz ER, 2010. Biotic diversity in the Southern African winter-rainfall region. Curr. Opin. Environ. Sustain. 2:109116.

Lindholm M, Hessen DO, Ramberg L, 2009. Diversity, dispersal and disturbance: cladoceran species composition in the Okavango delta. Afr. Zool. 44:24-35.

Löffler H, 1968. [Die Hochgebirgseen Ostafrikas]. [Article in German]. Hochgebirgsforschung 1:1-65.

Maiphae S, Pholpunthin P, Dumont HJ, 2008. Taxon richness and biogeography of the Cladocera (Crustacea, Ctenopoda, Anomopoda) of Thailand. Ann. Limnol-Int. J. Lim. 44:33-43.

Martens K, 1998. Diversity and endemicity of Recent nonmarine ostracods (Crustacea, Ostracoda) from Africa and South America: a faunal comparison. Verh. Internat. Verein. Theor. Angew. Limnol. 26:2093-2097.

Mergeay J, Verschuren D, De Meester L, 2005. Daphnia species diversity in Kenya, and a key to the identification of their ephippia. Hydrobiologia 542:261-274.

Mergeay J, Verschuren D, De Meester L, 2006. Invasion of an asexual American water flea clone throughout Africa and rapid displacement of a native sibling species. P. R. Soc. B 273:2893-2844.

Methuen PA, 1910. Crustacea from the Transvaal, p. 148-166. In: Proc. of the Zoological Society of London, Academic Press.

Methuen PA, 1911. Transvaal Crustacea. 1. Ann. Transv. Mus. 2:253-256.

Orlova-Bienkowskaja MY, 2001. Daphniidae: genus Simocephalus. Guides to the identification of the microinvertebrates of the continental waters of the World. 17th ed. Backhuys, Leiden: 130 pp.

Petrusek A, Tollrian R, Schwenk K, Haas A, Laforsch C, 2008. 
A "crown of thorns" is an inducible defense that protects Daphnia against an ancient predator. P. Natl. Acad. Sci. USA 106:2248-2252.

Picker MD, Samways MJ, 1996. Faunal diversity and endemicity of the Cape Peninsula, South Africa - a first assessment. Biodivers. Conserv. 5:591-606.

Reid JW, Bayly IAE, Pesce GL, Rayner NA, Ranga Reddy Y, Rocha CEF, Suárez-Morales E, Ueda H, 2000. Conservation of continental copepod crustaceans, p. 253-261. In: E. Escobar-Briones, F. Alvarez (eds), Modern approaches to the study of crustacea. Kluwer Academic/Plenum Publishers.

Rey J, St-Jean L, 1968. [Les Cladocères (Crustacés, Branchiopodes) du Tchad, (première note)]. [Article in French]. Cah. ORSTOM Hydrobiol. 2:79-118.

Rey J, St-Jean L, 1969. [Les Cladocères (Crustacés, Branchiopodes) du Tchad (deuxième note)]. [Article in French]. Cah. ORSTOM Hydrobiol. 3:21-42.

Richard J, Clark PF, 2009. African Caridina (Crustacea: Decapoda: Caridae: Atyidae): redescriptions of C. africana Kingsley, 1882, C. togoensis Hilgendorf, 1893, C. natalensis and $C$. roubaudi Bouvier, 1925 with descriptions of 14 new species. Zootaxa 1995:1-75.

Richardson JE, Weitz FM, Fay MF, Cronk, QCB, Linder HP, Reeves G, Chase MW, 2001. Rapid and recent origin of species richness in the Cape flora of South Africa. Nature 412:181-183.

Rühe FE, 1914. [Die Süsswassercrustaceen der Deutschen Südpolar-Expedition 1901-1903 mit Ausschluss der Ostrakoden. Deutsche Südpolar-Expedition, 1901-1903]. [Article in German]. Zoologie 16:5-66.

Sars GO, 1895. On some South-African Entomostraca raised from dried mud. Videnskabs-Selskabets Skrifter, I. Mathematic-Naturvidenskab Klasse 8:1-56.

Sars GO, 1898. On Megalocypris princeps, a giant fresh-water ostracod from South-Africa. Arch. Math. Naturvidensk. 20:1-18.

Sars GO, 1916. The fresh-water Entomostraca of the Cape Province (Union of South Africa). 1. Cladocera. Ann. S. African Mus. 15:303-351.

Seaman MT, Kok DJ, Watson M, 1999. Cladocera, p. 81-110. In: J.A. Day, B.A. Stewart, I.J. De Moor and A.E. Louw (eds.), Guides to the freshwater invertebrates of South Africa. Crustacea I. Water Reasearch Commission Report, TT121/00. South African Water Reasearch Commission Publ.

Segers H, De Smet WH, 2008. Diversity and endemism in Rotifera: a review, and Keratella Bory de St Vincent. Biodivers. Conserv. 17:303-316.

Sinev AY, 2006. Alona meridionalis sp.n. - a new species of Chydoridae (Branchiopoda: Cladocera: Anomopoda) from South Africa, with transverse lateral head pores. Arthropoda Selecta 15:193-202.

Sinev AY, 2008. A new species related to Alona costata Sars, 1862 (Cladocera: Anomopoda: Chydoridae) from South Africa. Zootaxa 1707:23-36.

Sinev AY, 2009. Cladocerans of the Alona affinis (Leydig, 1860) group from South Africa. Zootaxa 1990:41-54.

Sinev AY, Alonso M, Miracle MR, Sahuquillo M, 2012. The West Mediterranean Alona azorica Frenzel \& Alonso, 1988 (Cladocera: Anomopoda: Chydoridae) is composed of two species. Zootaxa 3276:51-68.

Smirnov NN, 1971. [Chydoridae of the world fauna. Fauna
SSSR]. [Article in Russian]. Rakoobraznie 1:1-531.

Smirnov NN, 1976. [Macrothricidae and Moinidae of the world fauna]. [Book in Russian]. Nauka, Leningrad: 237 pp.

Smirnov NN, 1992. The Macrothricidae of the world. Guides to the identification of the microivertebrates of the continental waters of the world. SPB Academic Publ., The Hague: 143 pp.

Smirnov NN, 2007. Pleuroxus-like chydorids (Crustacea: Anomopoda) from South Africa, with the description of $\mathrm{Du}$ montiellus africanus gen. n., sp. n. Hydrobiologia 575:433439.

Smirnov NN, 2008. Check-list of the South-African Cladocera (Crustacea: Branchiopoda). Zootaxa 1788:47-56.

Smirnov NN, Kotov AA, 2010. The morphological radiation of setae of the Cladocera (Crustacea) and their potential for morphogenesis. Int. Rev. Hydrobiol. 95:482-519.

Smirnov NN, Kotov AA, Coronel J, 2006. Partial revision of the aduncus-like species of Pleuroxus Baird, 1843 (Chydoridae, Cladocera) from the southern hemisphere with comments of subgeneric differentiation within the genus. J. Nat. Hist. 40:1617-1639.

Thieme ML, Abell R, Burgess N, Lehner B, Dinerstein E, Olson D, Teugels G, Kamdem-Toham A, Stiassny MLJ, Skelton P, 2005. Freshwater ecoregions of Africa and Madagascar: a conservation assessment. Island Press, Washington DC: 483 pp.

Van Damme K, Dumont HJ, 2008a. Further division of Alona Baird, 1843: separation and position of Coronatella Dybowski \& Grochowski and Ovalona gen.n. (Crustacea: Cladocera). Zootaxa 1960:1-44.

Van Damme K, Dumont HJ, 2008b. The 'true' genus Alona Baird, 1843 (Crustacea: Cladocera: Anomopoda): position of the A. quadrangularis-group and description of a new species from the Democratic Republic of Congo. Zootaxa 1943:1-25.

Van Damme K, Dumont HJ, 2009. Notes on chydorid endemism in continental Africa: Matralona gen. n., a monotypic alonine from the Fouta Djalon Plateau (Guinea, West Africa) (Crustacea: Cladocera: Anomopoda). Zootaxa 2051:26-40.

Van Damme K, Dumont HJ, 2010. Cladocera of the Lençóis Maranhenses (NE - Brazil): faunal composition and a reappraisal of Sars' Method. Braz. J. Biol. 70:755-779.

Van Damme K, Eggermont H, 2011. The Afromontane Cladocera (Crustacea: Branchiopoda) of the Rwenzori (Uganda D. R. Congo): taxonomy, ecology and biogeography. Hydrobiologia 676:57-100.

Van Damme K, Kotov AA, Dumont HJ, 2010. A checklist of names in Alona Baird 1843 (Crustacea: Cladocera: Chydoridae) and their current status: an analysis of the taxonomy of a lump genus. Zootaxa 2330:1-63.

Van Damme K, Sinev AY, Dumont HJ, 2011. Separation of Anthalona gen.n. from Alona Baird, 1843 (Branchiopoda: Cladocera: Anomopoda): morphology and evolution of scraping stenothermic alonines. Zootaxa 2875:1-64.

Wagler E, 1936. [Die Systematik und geographische Verbreitung des Genus Daphnia O. F. Mueller mit besonderer Berucksichtigung des sudafrikanischen Arten]. [Article in German]. Arch. Hydrobiol. 30:505-556.

Wishart MJ, Day JA, 2002. Endemism in the freshwater fauna of the south-western Cape, South Africa. Verh. Internat. Verein. Theor. Angew. Limnol. 28:1762-1766. 